\title{
Understanding What Influences Successful Black Commuter Students' Engagement in College: An Exploratory Study
}

\author{
Trina Lynn Yearwood \\ West Virginia University
}

Follow this and additional works at: https://researchrepository.wvu.edu/etd

\author{
Recommended Citation \\ Yearwood, Trina Lynn, "Understanding What Influences Successful Black Commuter Students' \\ Engagement in College: An Exploratory Study" (2011). Graduate Theses, Dissertations, and Problem \\ Reports. 3558. \\ https://researchrepository.wvu.edu/etd/3558
}

This Dissertation is protected by copyright and/or related rights. It has been brought to you by the The Research Repository @ WVU with permission from the rights-holder(s). You are free to use this Dissertation in any way that is permitted by the copyright and related rights legislation that applies to your use. For other uses you must obtain permission from the rights-holder(s) directly, unless additional rights are indicated by a Creative Commons license in the record and/ or on the work itself. This Dissertation has been accepted for inclusion in WVU Graduate Theses, Dissertations, and Problem Reports collection by an authorized administrator of The Research Repository @ WVU. For more information, please contact researchrepository@mail.wvu.edu. 
Understanding What Influences Successful Black Commuter Students' Engagement in College: An Exploratory Study

Trina Lynn Yearwood

Dissertation submitted to the College of Human Resources and Education at West Virginia University in partial fulfillment of the requirements

for the degree of

Doctor of Education

in

Educational Leadership

Elizabeth A. Jones, Ph.D., Chair

Ernest R. Goeres, Ph.D.

Peter Grant Jordan, Ed.D.

Ann Richards, Ph.D.

Richard Walls, Ph.D.

Department of Educational Leadership Studies

Morgantown, West Virginia

2011

Copyright 2011

Trina Lynn Yearwood

ALL RIGHTS RESERVED 


\begin{abstract}
Understanding What Influences Successful Black Commuter Students' Engagement in College: An Exploratory Study

Trina Lynn Yearwood

Although Black commuter students are disadvantaged when it comes to higher education, research on the success of Black commuter students in college is very rare. Existing research on Black and commuter students primarily concentrate on negative statistics such as stagnant college completion rates, departure, and lack of engagement. The purpose of this study is to assess successful Black undergraduate commuter students' engagement in educational practices associated with high levels of learning and development on City University of New York (CUNY) campuses in an attempt to improve student engagement and, ultimately, learning. This research study focuses on successful Black senior students at CUNY who have maintained at least a C overall grade point average (GPA).
\end{abstract}

Quantitative research methods were utilized to examine what influences successful Black students' engagement at CUNY commuter colleges. The analysis of 2009 National Survey of Student Engagement (NSSE) data found that significant differences in levels of engagement existed for students who are members of Greek organizations; students who interact with faculty often; and students who often participate in co-curricular activities. 
This document is dedicated to Carlisle D. Yearwood who always encouraged me to "aim high." 


\section{ACKNOWLEDGMENTS}

Never would have made it

Never could have made it without You

I would have lost it all

But now I see how You were there for me

-Marvin Sapp's Never Would Have Made It, 2007

First, I'd like to thank God for giving me the wisdom and strength to walk in my purpose and for guiding me every step of the way. Each time I reflect on this journey, the words of Marvin Sapp's song Never Would Have Made It pop in to my head and remind me that I truly never would have made without Him.

I thank my parents for pushing me to succeed academically at a very young age. I especially thank my mother and grandmother for the sacrifices they have made in order for me to accomplish this goal. Mommy, you gave up your dreams to devote your time to raising a family and to making sure we understood the value of education. You have supported me every step of the way. You are selfless and simply wonderful, and I could not have done this without you! I am truly blessed and honored to call you my mother. I eagerly anticipate that job so that I can bless you as you've blessed me. Thank you, mommy. I love you! Aunt Sybil, thank you for never allowing me to be mediocre. You taught me how to always trust God and put forth my best. Your prayers have carried me through. When I aim for perfection, I aim to be like you. I love you. Mommy and Aunt Sybil, I hope you can finally see your deferred dreams manifested through me! This degree is for you! 
I thank my better half, Gunnar Dessources, for being by my side when things got rough and pushing me when I needed to be pushed. You were there from day one of this journey and have kept me grounded. You never doubted me even when I doubted myself. Your words of encouragement always help me remember my obligation in the field of education. Thank you for listening to me read my dissertation in the wee hours of the morning and being there when I needed you most. I appreciate and love you.

To my siblings, Marcia and Eric; my second dad, Glenny; my sistercousinsororforlife, Nat; my sisky pooh, Angy; and my brother-in-law, Darrellthank you all for your support! You all have each played a significant role in my life throughout this doctoral journey. From rides to the airport to encouraging words, I love all of you dearly! I thank my entire family (blood and extended) for their support and love. They say you can't choose family, but if I could, I would choose you all over again...hands down!

Many thanks to my mentor, Mrs. Barton, for encouraging me and always believing in me. I chose the field of education because I wanted to walk in your footsteps. I especially thank you for insisting that I enroll in Mrs. Zarneski's research writing class during my senior year of high school. That class gave me the foundation that I needed to accomplish this!

To my chair, Dr. Elizabeth Jones: Dr. J, I thank you for believing in me and pushing me to complete through all the changes! Thank you for always being available when I needed you. Your words of encouragement have been nothing but inspirational. It wasn't easy transitioning from public school to higher education, but I have learned so much about higher ed because of you. Thank you for ensuring a smooth transition. 
To my WVU committee, Drs. Goeres, Richards and Walls: Thank you for your guidance, time, patience, and suggestions. I could not have completed this without you. I appreciate you all agreeing to serve on my committee in spite of your busy schedules-I am eternally grateful! Dr. Goeres, enjoy the retirement that you've earned and you deserve!

To Dr. Peter Grant Jordan: Dr. Jordan, you have been nothing but amazing! In spite of your VP role, you always made time for me. Your advice and frequent emails and phone calls to make sure I was on the right path are greatly appreciated. Thank you.

To CUNY's Assistant Dean for Institutional Research—Dr. Cheryl Littman: Thank you for providing me with the data to complete my dissertation study. Your support of this endeavor, from my initial email, is appreciated!

A special thank you to Dr. William Bannon! Bill, you helped me get through stats (again) and complete this analysis in record time! Thanks.

To my WVU cohort crew—Michelle, Gaby, Twyla, Sherri and Mike—I love you all! From Election Day lawn signs to the emergency room to Kuda Brown to motion sickness through the mountains of West Virginia and Fred's...we've been through it all! These five memorable years at WVU will forever be etched in my mind and on my heart! Thank you all for your support and for teaching the higher ed "Neo" of the group all about higher education.

Thank you to Jennifer McIntosh and the WVU Office of Social Justice for inviting me to be a Chancellor's Scholar and for your support throughout the program.

Thank you to the Department of Africana Studies at Brooklyn College. It was the presence of your department on campus that made me a successful Black commuter 
student! Africana Studies ensured a high Level of Academic Challenge; provided me with opportunities for Active and Collaborative Learning and Student-Faculty Interaction; promoted and encouraged Enriching Educational Experiences; and was my own personal Supportive Campus Environment. In my eyes, the Department of Africana Studies is synonymous with college student engagement—-thank you for enhancing my college experience!

Thank you to Candace P. Keeby for your many emails—especially the one that led me to WVU. I wouldn't have been here without you!

A special thank you to Jonathan \& Tamisha Ajose who welcomed me as their monthly houseguest when traveling to and from West Virginia! I love you both!

To my friends, thank you to each and every one of you who helped me along the way. There is nothing like friends!

To my oh so sweet, sensational and phenomenal sisters of Zeta Phi Beta Sorority, Incorporated, I thank you for encouraging me to strive for excellence and uphold our principle of scholarship. Thank you for investing in one of your own. 


\section{TABLE OF CONTENTS}

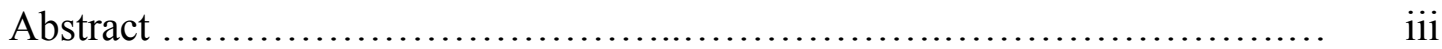

Acknowledgements ............................................... iv

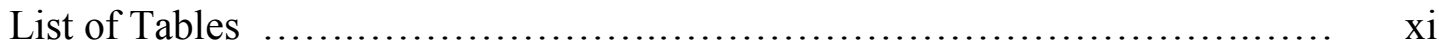

CHAPTER ONE: Statement of the Problem ............................ 1

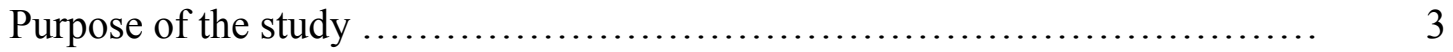

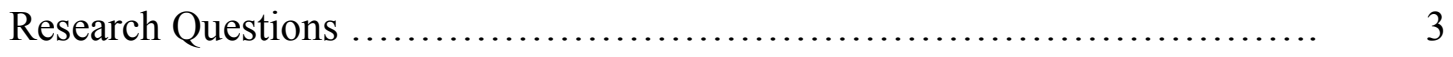

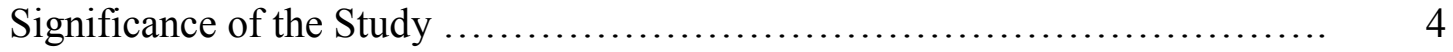

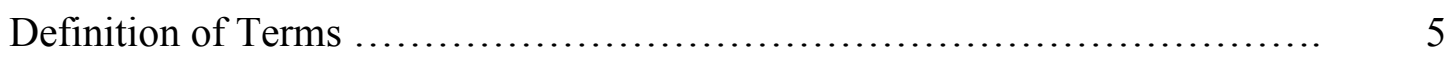

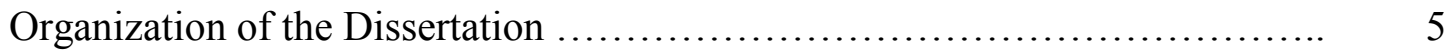

CHAPTER TWO: Review of Literature................................ 7

History of Blacks in Higher Education ............................... 7

Theories Related to Student Engagement $\ldots \ldots \ldots \ldots \ldots \ldots \ldots \ldots \ldots \ldots \ldots \ldots \ldots . \quad 10$

Student Engagement and Black Students ............................. 14

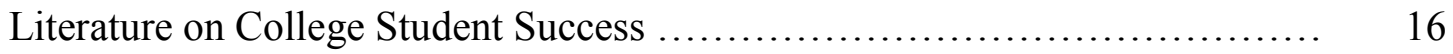

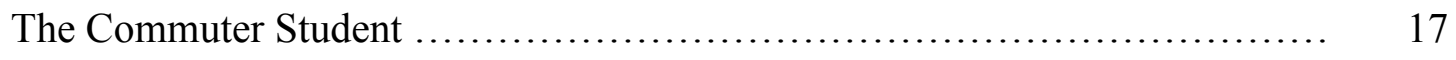

National Survey of Student Engagement ............................... 20

CHAPTER THREE: Methodology ................................... 25

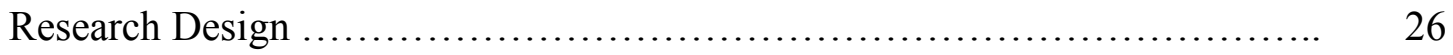

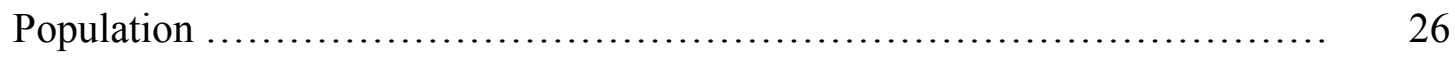

Data Collection Method and Instrumentation ........................... 27

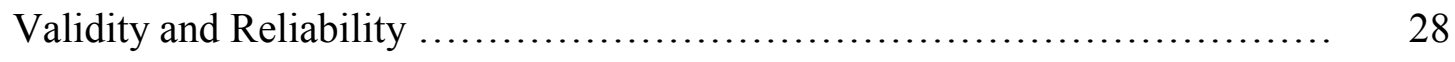

Specific Description of Data Analysis ............................... 29 


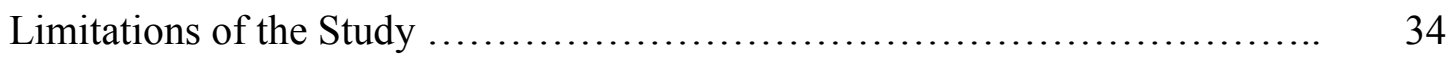

CHAPTER FOUR: Results and Discussions............................. 35

Overview..................................................... 35

Survey Process................................................... 36

Missing Data.................................................... 36

Measurements......................................................... 36

Demographic Results............................................ 52

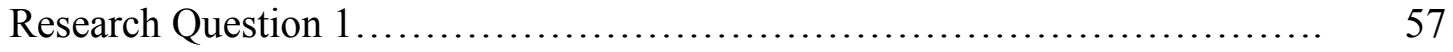

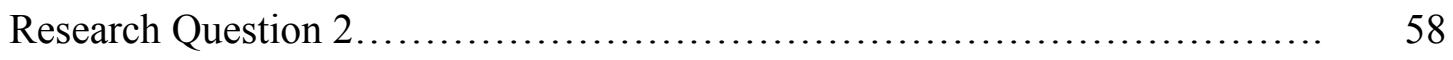

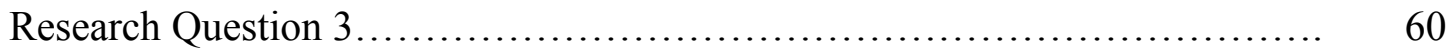

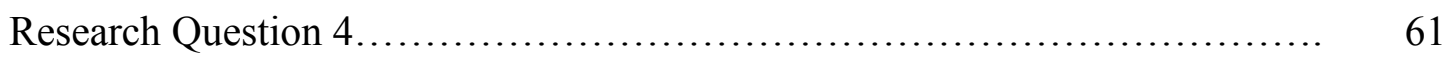

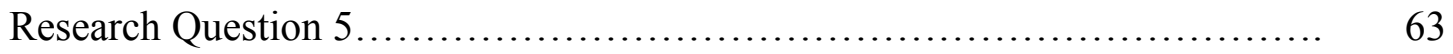

CHAPTER FIVE: Summary and Conclusions.......................... 66

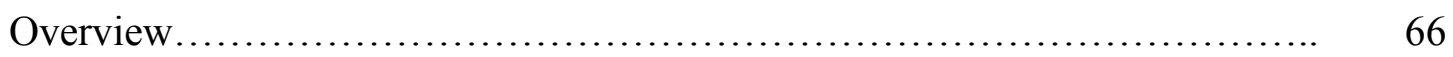

Summary of Results.............................................. 66

Conclusions.................................................... 68

Areas of Engagement................................................... 68

Gender....................................................... 74

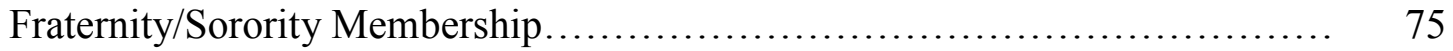

Parents Education................................................. 76

Co-Curricular Activities.............................................. $\quad 77$

Implications for Policy and Practice................................ $\quad 77$

Promoting Benefits and Visibility of Fraternities and Sororities.............. 78 
Enhancing Student-Faculty Interaction............................. 80

Enhance Participation in Co-Curricular Activities.......................... 86

Enhancing Student Affairs and Academic Affairs Collaboration.............. 88

Develop Scholarly Research \& Writing Skills.......................... 89

Recommendations for Future Research.............................. 89

Conducting Interviews with Black Students who are Less Engaged than Their

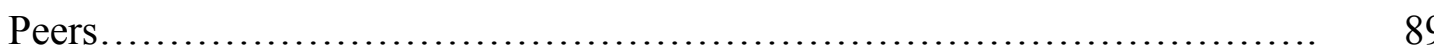

Investigating Significant Differences between New York City Public School

Students and Non-New York City Public School Students.................. $\quad 90$

Investigating Significant Differences between CUNY Freshman Students

who Participated in Collaborative Programs and CUNY Freshman Students

who Did Not Participate in Collaborative Programs........................ 90

Investigating Significant Differences by Race/Ethnicity.................. 91

Investigating Significant Differences by Colleges........................ 91

Investigate the Impact of the Black Male Initiative (BMI) on Black Male

Engagement..................................................... 92

Investing Significant Differences by Academic Major.................... 92

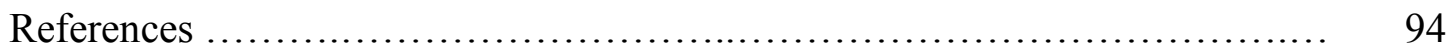

APPENDIX A: National Survey of Student Engagement (NSSE) ............ 107

APPENDIX B: Letter Requesting NSSE Data to Conduct Study ............ 111 


\section{LIST OF TABLES}

Table 1: Connections between Research Questions and Survey Items......... 33

Table 2: Level of Academic Challenge (LAC)......................... 40

Table 3: Active and Collaborative Learning (ACL)....................... 43

Table 4: Student-Faculty Interaction (SFI) ......................... 45

Table 5: Enriching Educational Experiences (EEE) $\ldots \ldots \ldots \ldots \ldots \ldots \ldots \ldots \ldots \ldots, 47$

Table 6: Supportive Campus Environment (SCE) $\ldots \ldots \ldots \ldots \ldots \ldots \ldots \ldots \ldots \ldots \ldots \ldots \ldots \ldots$

Table 7: Gender of Participating Students............................ 52

Table 8: College of Participating Students............................ 53

Table 9: U.S. Citizenship of Participating Students...................... 54

Table 10: Enrollment Status of Participating Students................... 54

Table 11: Fraternity/Sorority Membership of Participating Students......... 55

Table 12: Living Situation of Participating Students..................... 55

Table 13: Parents' Level of Education of Participating Students............ 56

Table 14: GPA of of Participating Students.......................... 57

Table 15: T-test analysis Examining Mean Differences Between

Engagement Scales by Gender................................. 58

Table 16: T-test analysis Examining Mean Differences Between

Engagement Scales by Greek Membership......................... 60

Table 17: T-test analysis Examining Mean Differences Between

Engagement Scales by Parents Education.......................... 61

Table 18: T-test analysis Examining Mean Differences Between

Engagement Scales by Student-Faculty Interaction................... 62 
Table 19: T-test analysis Examining Mean Differences Between

Engagement Scales by Co-curricular Activity Participation................ 


\section{CHAPTER ONE}

\section{Statement of the Problem}

Black and commuter students are disadvantaged when it comes to higher education. Although Black students are enrolling in college more than they did in previous years, fewer are earning degrees compared to their counterparts (NCES, 2010). The Spelling Commission's 2006 report revealed that many of these students don't complete their degrees because, "most colleges and universities don't accept responsibility for making sure that those they admit actually succeed" (p. vii). According to Kuh et al. (2008), "Stagnant college completion rates and unacceptable racial-ethnic gaps in college graduation rates... have intensified the need to better understand the factors that influence student success in college" (p. 241).

Research asserts that students who live on campus are more engaged compared with students who commute (Chickering, 1974; Jacoby, 1989; Pascarella \& Terenzini, 1991). This is troubling because, for many years, researchers (Astin 1977, 1993; Kinzie

et al. 2008; Kuh 2003; Pascarella \& Terrenzini 1991, 2005) have posited that students benefit from an educational environment that engages in good practices. When these two demographics - Blacks and Commuters - are combined to create the Black commuter student, the chances of success are even more bleak.

In a 2008 study on student success, Kinzie et al. found that in terms of persistence, Black students benefit more than white students when they increase their levels of engagement in educationally effective activities. Clearly, for the Black commuter student, there should be heightened “...concern about whether campuses

effectively create engaging learning environments" (Kezar \& Kinzie, 2006, P. 149). 
According to Charles Hamilton Houston, "Without education, there is no hope for our people and without hope, our future is lost." What can be done to ensure a future of success for the Black commuter student?

The City University of New York (CUNY), is arguably the nation's largest public university system, services almost 300,000 students including undergraduates, graduates, returning professionals and approximately 45,000 high school students who are affiliated with CUNY's College Now (CN) Program (CUNY, 2010). CUNY's student body is remarkably diverse with approximately one third of the undergraduate population being Black (CUNY, 2011a). Student ancestries can be traced to two hundred five countries, and almost fifty percent of undergraduates have a native language other than English (CUNY, 2010). According to the Carnegie Classification System (2011), CUNY senior colleges are primarily non-residential. In a 2001 article about the City University of New York, Community College Week and Black Issues in Higher Education recognized CUNY's colleges for leading the nation in awarding degrees to minority students (CUNY, 2010).

CUNY leaders understand that the National Survey of Student Engagement (NSSE) “...is about facilitating the improvement of undergraduate education" (NSSE, 2009, p. 6) and recently used data from the NSSE to identify implications for increasing student engagement (CUNY, 2010). It is important to note that, “...within-institution variation far exceeds between-institution variation, meaning that students attending the same institution differ from each other a lot more than the average student at that institution differs from those at other institutions" (NSSE, 2008, p. 12). As a public university system with a history of large numbers of minority students earning degrees, it 
would be meaningful for CUNY administrators to analyze within-institution data to identify engagement benchmarks that contributed to the success of Black students.

CUNY also participates in the Access to Success Initiative, which is a project of the National Association of System Heads and The Education Trust. This program “....seeks to improve overall student success and to dramatically reduce current disparities in the college enrollment, retention, and graduation rates of low-income and underrepresented groups by 2015 " (edtrust.org, 2010).

\section{Purpose of the Study}

The purpose of this study is to assess successful Black college students' engagement in educational practices associated with high levels of learning and development on CUNY campuses in an attempt to improve student engagement and, ultimately, learning.

\section{Research Questions}

This study will address the following research questions:

1. Is there a statistically significant difference between the levels of college engagement for successful Black female students and successful Black male students?

2. Is there a statistically significant difference between the levels of college engagement for successful Black fraternity and sorority members and successful non-members?

3. Is there a statistically significant difference between the levels of college engagement for successful students whose parents completed a college degree (at least one parent with an associate's degree or higher) and successful students 
whose parents did not complete a college degree (both parents attended college but did not complete a degree or lower)?

4. Is there a statistically significant difference between the levels of college engagement for successful Black students who interact with faculty often and notoften?

5. Is there a statistically significant difference between the levels of college engagement for successful Black students who participate in co-curricular activities often (16 or more hours) and those who do not (15 or less hours)?

\section{Significance of the Study}

According to the National Survey of Student Engagement (NSSE), "engagement yields larger payoffs in terms of grades and retention for underprepared students and historically underrepresented students relative to otherwise comparable peers" (2009, p. 6). Although approximately $85 \%$ of students in higher education commute to campus (Horn et al., 2006), there is very little research about the levels of engagement and learning among commuter students. There is even less research about Black students who commute. The need for research about undergraduate commuter students dates back to the 1960's (Bean \& Metzner, 1985). Since NSSE emphasizes “...the importance of disaggregating an institution's data to examine the patterns of engagement" (NSSE, 2008, p. 12), this study will disaggregate a university's NSSE data to examine the patterns of engagement among Black commuter students. This study will offer recommendations to administrators and faculty in higher education that could help enhance the success of Black commuter students. Institutions of higher 
education, especially minority-serving, commuter colleges, must ensure that all students acquire the necessary skills to succeed in school and become productive citizens once they graduate.

\section{Definition of Terms}

Black: Black refers to those non-Hispanic persons of African descent from the Diaspora. Included in this definition of Black are persons from the Caribbean and Africa who currently reside and/or attend school in the United States.

Commuter Student: Students who do not live in institution-owned housing. Student Engagement: The time and energy that students devote to educationally purposeful activities and the extent to which the institution gets students to participate in activities that lead to student success. (Kuh et al., 2008).

Success: According to the Association of American Colleges and Universities (AACU, 2007), "Student success in college cannot be documented — as it usually is —only in terms of enrollment, persistence, and degree attainment" (p. 1). For the purposes of this study, however, success is defined as senior students who have maintained at least a $\mathrm{C}$ overall grade point average (GPA) at CUNY because a C average is required to get a diploma. Educationally Effective Activities: Aspects of the student experience that contribute to learning and personal development. This is interchangeable with educationally purposeful activities/practices.

\section{Organization of the Dissertation}

This chapter briefly outlined the stated problem and current issues pertaining to the success of Black commuter students in higher education. It also introduced student 
engagement and the research questions that guided the examination of the problem. Chapter Two provides a detailed literature review of relevant research elucidating the history of Blacks in higher education, theories related to engagement, Black student engagement, attempts to improve the college experience for Black undergraduates and commuter students through engagement and retention efforts as well as the use of NSSE data. Chapter Three explains the rationale for the quantitative research methodology, selected participants, data analysis, and limitations of the study. Chapter Four explains the data analysis and reports the results. Chapter Five summarizes the study, discusses implications for policy and practice, and recommends future research. The survey instrument and letter requesting data are attached to the dissertation as appendices. 


\section{CHAPTER TWO}

\section{Review of Literature}

Research on the success of Black commuter students in higher education is very rare. This research study focuses on analyzing Black student success and its relation to levels of engagement at commuter schools. There are studies that confirm the importance of involvement (Astin 1977, 1993) and engagement (Kuh 1993; Flowers 2004) for [Black] students. There are also a number of studies that focus on retention and departure (Braxton et al., 2004; Nora and Cabrera 1996). In the preface to his 1982 book Minorities in American Higher Education, Astin asserted "that there is much the higher education system can do to further the cause of minorities in higher education..." (p. ix). Nearly three decades later, that claim still holds true. The implications from this study will provide suggestions regarding what university administrators and faculty can do to further the engagement and retention of Black students at commuter schools.

In this chapter, I will review relevant literature that focuses on Black students in higher education. I will begin the review with a look at the history of Blacks in higher education. I will also focus on theories related to the development of student engagement as well as research related to Black student success. Finally, I will discuss differences between the commuter student and the residential student and highlight NSSE's impact on Black students.

\section{History of Blacks in Higher Education}

Higher education in the United States began as a privilege that was reserved for an elite few - those students whose parents were wealthy or held prominent positions in society (Morison, 1936). Unfortunately, this excluded Blacks. In fact, Blacks attending 
college was a rarity. In the South, Blacks were not allowed to attend college and very few were allowed to attend white colleges in the North. Prior to the Emancipation Proclamation, no more than 27 Blacks graduated from college (Lucas, 2006).

The period following the Emancipation Proclamation seemed to present new opportunities for formerly enslaved Africans including an education. Abolitionists and missionary groups expected free Blacks to be educated. With the assistance of Black normal schools and Black churches, many of these newly freed citizens were able to develop skills through a vocational education. The idea of educated Blacks, however, wasn't widely accepted.

The Morrill Act of 1890, unlike its predecessor in 1862, attempted to end educational segregation for Blacks and made provisions by providing federal support for land-grant institutions including those for Blacks. These new Black land-grant institutions, now known as Historically Black Colleges and Universities (HBCU's), made college accessible to Black farmers and working class people. These once excluded citizens now had an opportunity to obtain higher education.

For many years, HBCU's served as the only postsecondary option for Blacks (Fleming, 1984; Laird et al., 2007). “Of the approximately 45,000 Black students enrolled in higher education at the beginning of World War II, only about one in ten was enrolled in a predominantly white college or university" (Mingle in Thomas, 1981, p. 18). In the years after WWII, however, “...major steps were taken to encourage the enrollment of...Black students" (Cohen, 1998, p.198) and about seven in ten could be found at white institutions (Mingle in Thomas, 1981, p. 18). Leaders of institutions of higher education realized the inevitable changes in the post-secondary system and wanted 
to "... attract students to break down all academic, attitudinal, and economic barriers" (Cohen, 1998, p. 197). During this time, the G.I. Bill and financial aid, including federal loans and grants, were made available to those who couldn't afford tuition. The once marginalized student now had access to college. Although enrollment efforts shifted the campus scene markedly, the climate of the institution was still cruel, which caused many Black students to face social exclusion within the campus (Thelin, 2004).

Social exclusion was the impetus of student activism on college campuses. Between the 1960's and 1970's, Black students started a movement to ensure their success in college. Student activism of the 1960's served as a revolution, which left no campus untouched. "Students at the traditionally black institutions in the south were especially involved, and many white students from Northern and Southern colleges participated along with them" (Cohen, 1998, p. 202) to implement change in communities and campuses across the nation. These students devoted a lot of time and energy to activities that can be deemed educationally purposeful. Sit-ins and protests occurred both on and off-campus. Black students were deeply involved and fought for an education that was both relevant to what was happening in their communities as well as indicative of what they wanted to study. Both student-faculty interactions and studentstudent interactions increased. This new level of student involvement in American higher education to protest “... an unpopular war, [for] civil rights, access to college, [and] curricular and instructional forms..." (Cohen, 1998, p. 203) brought about unforgettable change on college campuses and society. College and university leaders demonstrated their commitment to fostering student success by encouraging the formation of oncampus student groups and organizations, creating Black cultural centers, and making 
changes to the curriculum including the creation of new academic programs (such as Black studies) and new academic support systems for Black students. All of these initiatives sought to ensure Black students' success and tended to increase the proportion “...of Blacks who had completed four or more years of college...by more than 150 percent” (Astin et al., 1982, p. 87). Based on these students' level of involvement and engagement, one can argue that student "engagement" has its roots embedded in the activism displayed by Black students in the 1960's. By the early 1980's, however, “the time to graduate increased, GPA's decreased, attrition rates increased, and matriculation to grad school decreased" for Black students (LaBoone, 2004, pp.5-6). Although the outcomes of student activism are ever-present, the rates of success for Black students don't match that growth.

\section{Theories Related to Student Engagement}

Kuh and colleagues (2010) assert that "decades of research studies on college impact and persistence suggest a promising area of emphasis: student engagement" (p. 7). They define student engagement as a two part phenomenon that includes the time and energy students devote to educationally purposeful activities and the extent to which the institution gets students to participate in activities that lead to student success (Kuh et al., 2008). Engagement is simply "a two way street” (Kuh, 2009, p. 696).

Student engagement can be traced back to the work of Astin (1984), Pace (1984), and Kuh and his colleagues (1989). Although these researchers, "used different terminology to describe their concepts of student engagement, their views were based on the simple, but powerful, premise that students learn from what they do in college" (Pike and Kuh, 2005, p. 186). Pascarella and Terenzini (1991) sum it up by stating "one of the 
most inescapable and unequivocal conclusions we can make is that the impact of college is largely determined by the individual's quality of effort and level of involvement in both academic and non-academic activities" (p. 610).

Astin's involvement theory. Astin's involvement theory is at the core of student engagement. Initially, Astin's student involvement theory “endeavored to identify factors in the college environment that significantly affect the student's persistence in college" (Astin, 1999, p. 523). This study identified factors that led to persistence which suggested involvement; factors that led to dropping out suggested lack of involvement. Astin's theory of involvement found that the more students are involved in both the academic and social aspects of the college experience the more they learn. In other words, an involved student “...devotes considerable energy to studying, spends much time on campus, participates actively in student organizations, and interacts frequently with faculty members and other students" (Astin, 1999, p. 518).

Tinto's model of college student departure. While Astin's theory focuses on involvement in the academic and social aspects of the college or university, Tinto's (1975) model of college student departure focuses on the different characteristics that influence students' decisions to leave their college or university. These characteristics include socioeconomic status, precollege experiences, and individual traits. Tinto suggested that a student's level of social and academic integration to the university determine that student's commitment to persist to graduation. Students that were both socially and academically integrated into the college experience had decreased chances of departure. Tinto later added (1993) that students had to experience a "rites of passage" 
where they disassociated themselves from their families and significant others in order to become full members of the university.

Tierney's cultural model. Tierney (1997) presented a cultural framework for analyzing participation in higher education, which opposed Tinto's rites of passage theory. Tierney (1999) argued that Tinto's model did not respect the fact that Black students' “...cultural backgrounds differ in significant ways...” (p. 82). Tierney suggested that organizations create an environment where each student's identity and culture is affirmed and honored. He proposed the following five key points to ensure academic success:

1. Collaborative relations of power-Tierney argued that institutions of higher education cannot develop ways to integrate students into the system, but should rather develop ways to affirm and honor students' individual identities.

2. Connections across home, community and schooling — Tierney argued that in order for programs for minority students to be successful, institutions of higher education must acknowledge the backgrounds of those people they seek to educate. Institutions must begin working from where the students are and create activities that affirm their identities, homes and communities.

3. Local definitions of identity-Tierney argued that institutions of higher education must begin where students are at—intellectually, socially and emotionally—and "...have teachers, tasks and pedagogies that affirm who they are" (p. 11). 
4. Excellence-Tierney argued that institutions of higher education must raise the expectations of students and create a campus culture where all students can learn and succeed.

5. Academic support-Tierney argued that "programs that see individuals as broken and in need of repair are less likely to create conditions for success..." (p. 13). Tierney suggested that respect be a factor in creating programs that honors a student's position in order to help students succeed.

Tierney (1997) argues that "issues of racism... have been embedded in the way American education has been structured throughout history...” (p. 5). He concentrates on how institutions of higher education can be transformed into places where Black students thrive because "the overriding factor in success is when an individual feels part of [the institution]" (p. 11).

Pace's quality of effort theory. Pace (1984) created the College Student Experiences Questionnaire (CSEQ), which was designed to assess the quality of undergraduate student education and examine the sources of student progress toward the attainment of important goals of college education. The CSEQ was created to help college and university stakeholders better understand student learning and development, and increase accountability and evaluate programs in higher education. Pace contended that the quality of the educational experience should be taken into consideration. He also believed that all learning and development required an investment of time and effort by the student. The more effort a student invested, the more significant his or her educational experience. 
Pace asserted that while colleges are accountable for the different resources they provide to enhance the learning and development of the student, undergraduates ultimately were responsible for the effort invested in these offerings. Pace believed that the most important aspect of college life was what students did with the opportunities made available to them by the college.

Kuh et al.'s involvement theory. Kuh and his colleagues (1989) focused on leaders and administrators' contributions to an environment that promoted student involvement. They found that students seemed to gain more from their college experience when they were actively involved in both academic and out-of-class experiences and asserted that student involvement was the most important factor related to the quality of the educational experience. Kuh et al. also shed light on the responsibility and benefit of academic affairs and student affairs developing a partnership to encourage student engagement.

\section{Student Engagement \& Black Students}

The connection between student engagement and success is extensive (Laird et al., 2007). Laird et al. (2007) argue that:

there is an ongoing need to improve the cultures found at many institutions of higher education in terms of promoting the educational success of [Black] students...more needs to be known about how institutions shift from being an impediment to being a vehicle for student engagement and success...examining the characteristics of institutions that have done well, on average, with all of their students (p. 52) 
Flowers' (2004) study that examined the effects of Black students' involvement confirmed that Black students benefit from both in-class and out-of-class experiences. Additionally, involvement had a positive impact on academic and social integration, student development, and persistence. Flowers' (2004) study suggests that "appropriate types and amounts of student involvement experiences may significantly enhance [Black] students' educational outcomes in college" (p. 651). There should be a sense of urgency to get Black students engaged and involved because many of them still “...perceive the college environment to be less supportive" (Kinzie et al., 2008), which impedes their ability to succeed. Institutions of higher education must take deliberate measures to ensure that all students are engaged because "the very act of being engaged also adds to the foundation of skills and dispositions that is essential to live a productive and satisfying life after college" (Carini et al., 2006, p. 2).

Berger and Milem's 1999 study on involvement confirms the importance of a supportive campus environment for Black students. Their study found that while Black “...students enter the institution with strong levels of institutional commitment, they are less likely to perceive the institution as being supportive and less likely to persist" ( $\mathrm{p}$. $657)$.

Laird Townsend's 1994 research article, How Universities Successfully Retain and Graduate Black Students, contends that many black students “....are often forgotten and left to fend for themselves" once they matriculate (p. 85). Townsend, however, focused on institutions that go above and beyond to ensure that their Black students are retained and, ultimately, graduate. Among the colleges researched, including the University of Virginia, the University of South Carolina, Fisk University and Xavier 
College, the commonality in retaining students was getting them engaged and fostering a sense of community, care, and commitment.

It appears that “...virtually every reform report...[emphasizes] to varying degrees the important link between student engagement and desired outcomes of college" (Kuh, 2009, p. 684). Kuh asserts that without the analysis of data of students with different characteristics such as race, "the ability to leverage significant institutional change to increase student success will be severely limited" (p. 697). It is important to enhance the success of Black students at commuter schools because "...higher education serves as the principal gatekeeper for entry into [various] careers..." (Astin, et al., 1982, p. 1).

\section{Literature on College Student Success}

Malcolm Gladwell's definition of success in his 2008 book Outliers is consistent with Kuh et al.'s assertion that engagement is a two-part phenomenon. For Gladwell, success isn't only about one's talents and gifts, it is also about 1) how hard one works and 2) the "extraordinary opportunities" presented to the person (p. 55). If Gladwell's theory of success is applied to the Black student we would have something like this: if a Black student works hard in college and is presented with opportunities, then that student will be successful. At the commuter school, how much time or hard work do Black students devote to educationally purposeful activities and what opportunities are institutions of higher education presenting to ensure Black student engagement and active participation in these activities? Gladwell's book also echoes Astin's claim that what people actually $d o$ is one of the most important factors of success.

Gladwell shares the unfortunate story of Chris Langan — a genius who had an IQ that was 45 points higher than Albert Einstein's (p. 70). Chris Langan's intellectual 
superiority earned him a full scholarship to college. On the brink of his second semester, Chris's mother neglected to fill out financial forms necessary to renew the scholarship and, sadly, he lost it. When Chris attempted to negotiate his award at the scholarship office, he encountered staff who “... simply didn’t care... about their students...[and] there was no counseling, no mentoring, nothing” (p. 93). Although Chris Langan's story happened over thirty years ago, many students, Blacks in particular, still experience this sense of isolation from the campus and lack of support from faculty and staff. And like the college students who depart early, "Chris left...before the final set of exams, leaving him with a row of F's on his transcript. In the first semester, he had earned A's" (p. 93). Gladwell contends that Chris was not successful because "he'd had to make his way alone, and no one...ever makes it alone" (p. 115).

Williamson's 1999 study discusses the successful Black student during the 1960's \& 1970's. These students were characterized as those who “...excelled in academics and had clear career goals but who also fully participated in the Black student movement and the Black Power movement" (p. 102). The successful Black students cared about the welfare of all Black students and "beyond the campus... [was] expected to work for the collective good of the Black community" (p. 102). Unlike Chris Langan, these students did not have to worry about making it alone - they had each other. Black students, during that era, linked academic and social responsibility and often highlighted the importance of their participation in relevant things. Williamson asserts that Black students today can walk in the footsteps of the Black students from the ' 60 's and ' 70 's to ensure success because "until white institutions demonstrate a concerted commitment to 
Black students and their academic...survival, Black students will endeavor to create such an environment-in defense of themselves" (p. 104).

\section{The Commuter Student}

According to Jacoby (1989), much of the earlier literature on commuter students was “...rife with strongly negative characterizations...[which were]...based on observation rather than on carefully designed research...[and were]...cited repeatedly in other articles as authoritative sources of information" (p. 20). In spite of these troubling claims, “...the body of literature about commuter students is [still] limited in quantity and breadth" (Jacoby, 1989, p. 17). As a result, many assumptions emerged about the commuter student, which contributed to institutions of higher education's negligence to design “...policies, practices, and programs effectively to meet [commuter students'] needs and to encourage their involvement in learning" (Jacoby, 2000, p. 10).

One assumption is "...that commuters are like resident students except that they live off campus and that curricular and co-curricular offerings are equally appropriate for all students" (Jacoby, 1989, p. 1). In fact, the further a student lives from campus, the less involved that student will be (Kuh et al., 2001). In 1974, Chickering elucidated the "...need for creative programs that will broaden the college experience for the commuting student" (p. 53). Although there have been studies (Jacoby 1989, 2000; Kuh et al. 2001; Braxton et al. 2004) that “....emphasized the need to enhance the quality of the educational experience for commuter students" (Jacoby, 1989, p. 1), the need for creative programming for the commuter student still exists today.

Kuh et al. (2008), however, warn against simply offering programs to engage students. They insist that “...institutional programs and practices must be of high quality, 
customized to meet the needs of students they are intended to reach, and firmly rooted in a student success-oriented campus culture" (p. 556). Astin defines a high-quality institution as "...one that knows about its students... and has a method for gathering and disseminating this information, enabling it to make appropriate adjustments in programs or policies when the student data indicate that change or improvement is needed" (as cited in Jacoby, 1989, p. 41).

There are many factors that prevent commuter students from becoming involved in the same ways that traditional, residential students can (Jacoby, 1989). For the residential student, home and campus are synonymous; for the commuter student, the campus is simply a place to visit (Likins, 1988, as cited in Jacoby 2000). Jacoby (1989) contends that the fact these students "...commute to college profoundly influences the nature of their educational experience" (p.4).

"Commuter students' time on campus focuses primarily on classes..." (Braxton et al., 2004, p. 45) and leaves little time for meaningful interactions with other students and faculty in extracurricular activities. Since the classroom is the only regular venue that most commuter students have for interacting with other students and faculty, a high priority of its use should include creating communities of learning for a success-oriented campus culture (Kuh et al., 2008).

Jacoby (1989) credits “Chickering (1974) and Astin $(1975,1977)$ [for dominating] the second wave of literature regarding the experience of commuter students in higher education" (p. 21). Chickering's 1974 book Commuting versus Resident Students was the first book to focus on the commuter student. While Astin (1975) acknowledged the needs of commuter students, he focused on "traditional-age students" 
at "traditional collegiate institutions" (Jacoby, 1989, p. 21). There was no focus on the students at primarily non-residential institutions, which is one of the major limitations of earlier research on commuter students.

Jacoby (1989) asserts the need for institution-specific research on commuters in order to improve “...the quality of commuter students' educational experiences” (p. 26). Institutions of higher education are charged "...to conduct research and evaluation to determine to what extent [commuter] students' educational goals and needs are being met" (Jacoby, 1989, p. 41).

\section{National Survey of Student Engagement (NSSE)}

The National Survey of Student Engagement is an annual survey of undergraduates at four-year institutions that measures student engagement and the degree to which students are provided with an effective learning environment (Kuh, 2001a). Based on Chickering and Gamson's Seven Principles for Good Practice in Undergraduate Education, colleges and universities across the nation use the NSSE to determine how and where they can improve the undergraduate experience at their institution. Colleges and universities are encouraged to also use NSSE data to focus on how students are actually using the resources for learning that the institutions provide (Kuh, 2001b).

Institutions use their NSSE data to identify areas of engagement that can be enhanced both inside and outside of the classroom. According to the National Survey of Student Engagement (2008), “An engaged campus is one in which people actively collaborate to understand more about the student experience and work together to design better approaches and programs" (p. 4). 
NSSE identifies five benchmarks of effective educational practice associated with high levels of learning and development.

1. Level of Academic Challenge determines how challenging intellectual and creative work are. Questions in this benchmark include how much time students spend preparing for class and number of written papers or reports they write.

2. Active and Collaborative Learning determines how involved students are in their education. Questions in this benchmark include how often students participated in class discussions, made a class presentation and worked with classmates outside of class to prepare assignments.

3. Student-Faculty Interaction determines how much contact students have with their professors. Questions in this benchmark include whether students have worked with faculty members on activities outside of the classroom and whether students received prompt written or oral feedback from their professors.

4. Enriching Educational Experiences determines how much students participate in activities that complement the classroom learning experience. Questions in this benchmark include whether students have had serious conversations with students of a different race/ethnicity and whether students have studied abroad or participated in student clubs.

5. Supportive Campus Environment determines whether students perceive the campus as committed to their success or not. Questions in this benchmark include whether the campus provides the support students need to succeed and the quality of their relationships with students, faculty and administration. 
In addition to questions aligned with the benchmarks, students are asked to provide background information such as their sex, race/ethnicity, fraternity or sorority membership status, overall GPA, and highest level of parents' education. These important demographic variables provide an opportunity for researchers to analyze students' experiences according to certain student characteristics to see if there are significant differences in their engagement during their undergraduate enrollment.

Many college and university administrators and faculty use the results from NSSE to identify necessary reforms that can be made to foster student success. Although "Black students are somewhat underrepresented" (NSSE, 2010, p. 4), there are some institutions that use the results specifically to better meet the needs of minority students. For example, when administrators at the University of North Carolina Wilmington learned that minority students were not taking advantage of the career services center they created a mentoring program “...to connect students of color with business leaders in the community...[and] recruited minority staff and students to work in its career center" (Coleman, 2010, p. 1).

Similarly, after realizing underutilization of academic support services, administrators at Jackson State University (an HBCU) responded to the data and implemented changes to benefit the students who needed the services. As a result, they “... saw a 46 percent increase in students using tutorial services” (Coleman, 2010, p. 1). Historically Black Spelman College utilized NSSE data to develop a culture of critical thinking (NSSE, 2005, p. 24). Norfolk State University focused on NSSE's "Enriching Educational Experiences” benchmark to develop a Quality Enhancement Plan (QEP) for its students. NSSE results indicated significant progress in engagement for first-year 
students at Norfolk State University (IHEP, 2008, p. 3). Florida International University, a primarily non-residential institution, used NSSE results to improve the need for greater student support and created a Virtual Student Center “...to make information and support services available to students any time, anywhere, and to increase student engagement, satisfaction, and retention through to timely graduation" (IHEP, 2007, p. 5).

In 2002, the NSSE Institute for Effective Educational Practice in partnership with the American Association of Higher Education (AAHE) conducted the Documenting Effective Educational Practices (DEEP) project, which “...examined the everyday workings of a variety of educationally effective colleges and universities to learn what they do to promote student success" (Kezar \& Kinzie, 2006, p. 150). This two year study identified 4-year colleges and universities that participated in NSSE and had both higher than predicted student engagement results and higher than predicted six-year graduation rates in the educationally effective areas of Level of Academic Challenge, Active and Collaborative Learning, Student-Faculty Interaction, Enriching Educational Experiences, and Supportive Campus Environment.

The twenty exemplary institutions of higher education were credited for adding value to the student experience. These institutions included a variety of “...large, small, urban, and special mission colleges and universities" (NSSE Institute, 2011) to represent the diversity of American institutions of higher education. Each of the twenty DEEP institutions had a "living" mission and a "lived" educational philosophy; an unshakeable focus on student learning; environments adapted for educational enrichment; clearly marked pathways to student success; an improvement oriented ethos; and shared 
responsibility for educational quality and student success, which fostered "...student engagement and persistence" (Kuh et al., 2010, p. 24).

Kezar and Kinzie's (2006) study of DEEP institutions focused on student engagement and mission alignment and found "...that certain programs, policies, and approaches may work better based on [an] institution's mission" (p. 169). They encourage leaders to develop an engaging campus by creating programs and activities that are aligned with their institution's mission. Specifically, they suggest that, "Commuter campuses... utilize the diversity of their student body, part-time faculty, and location to create a particularly engaging environment" (p. 170).

In a 2010 analysis of student comments at the end of the NSSE, researcher Tony Chambers found that students at a primarily non-residential university were not very satisfied with their social experience. With a large commuter population, many of the students responded to these open-ended questions and shared their disappointment about the lack of opportunities to interact with diverse students and the cold climate of the institution. One student implored the university to improve student life in order to develop a strong feeling of community. Clearly, commuter students are in search of community and should no longer "...continue to be thought of as apathetic or uninterested in campus life" (Jacoby, 1989, p. 13). 


\section{CHAPTER THREE}

\section{Methodology}

Astin (1985) asserts that:

True excellence lies in the institution's ability to affect its students...favorably, to enhance their intellectual and scholarly development, and to make a positive difference in their lives. The most excellent institutions are...those that have the greatest impact... on the student's knowledge and personal development. (pp. 60-61)

According to CUNY's 2008-2012 Master Plan (2011b), the six-year "baccalaureate graduation rate has increased over the past six years from 31 percent to 42 percent" and there are more "Black...students enrolled in CUNY baccalaureate programs than in Fall 1999” (p. 2). These upward trends have encouraged CUNY's participation in the Access to Success Initiative, which improves overall student success and NSSE, which "has proven sufficiently instructive..." (p. 68). CUNY leaders understand that "student achievement is among the most important markers of any university's success" (p. 68). Through its proposed Co-curricular Transcript Program, CUNY encourages students to record their extra-curricular experiences to reinforce that “...involvement in campus and community life teaches [students] concrete, practical skills that significantly contribute to their personal and professional success during and after college" (p. 84). CUNY's recognition "...that educational success involves life not only within but also outside the classroom..." as well its commitment to "attending to both realms of student life" (p. 68) suggests that CUNY is dedicated to true excellence and would benefit from this 
dissertation research study that will offer recommendations to enhance the success of its Black students.

This chapter will provide a thorough description of this dissertation's research methodology. Quantitative methods have been chosen to conduct descriptive research to understand what influences successful Black commuter students' engagement in college. As with any study, there are limitations that will be addressed including the use of selfreported data that cannot be generalized for all institutions with commuter students.

\section{Research Design}

Quantitative methods were utilized to conduct descriptive, non-experimental research to analyze existing data. Quantitative research also explains a phenomenon (Muijs, 2004). According to Cramer (2003), "a major aim of the social...sciences is to develop explanations of various aspects of human behavior [and] one way of determining the...validity of explanations is to collect data pertinent to them..." (p. 1). Gall, Borg and Gall (1996), stated that, "the purpose of a survey is to use questionnaires to collect data from participants in a sample about their characteristics, experiences, and opinions in order to generalize the findings to a population that the sample is intended to represent" (p. 289). Muijs (2004) asserts that while quantitative research is quite flexible, it is important "...to use the right research design and data collection instruments" (p. 3). The research design used in this study is the NSSE — a quantitative survey questionnaire. The data for this study were based on a cross sectional design using the NSSE.

\section{Population}

The target population for this study was Black undergraduate commuter students. The researcher studied Black commuter students at the City University of New York 
(CUNY) because CUNY is primarily non-residential, and the majority of students commute. The researcher talked to CUNY's Assistant Dean for Institutional Research who shared that of the 7,700 seniors that were sampled approximately $1,100(15 \%)$ completed the National Survey of Student Engagement survey in the spring 2009 semester. Two hundred eighty surveys were analyzed since this was the number of respondents who met the researcher's criteria. This survey was sent to all first-year and senior students at CUNY's 11 senior colleges. However, the researcher only examined the responses from Black commuter students who completed the survey as seniors while enrolled in CUNY. All of these participants voluntarily completed the survey.

\section{Data Collection Method \& Instrumentation}

Approval from West Virginia University's Institutional Review Board for the Protection of Human Subjects (IRB) was obtained before any formal research on the dissertation began. The researcher also obtained approval from CUNY's IRB. The 2009 version of the NSSE, which was administered in the Spring, was utilized for this dissertation research study. The National Survey of Student Engagement (NSSE) “. . . documents dimensions of quality in undergraduate education and provides information and assistance to colleges, universities, and other organizations to improve student learning” (NSSE, 2006, p. 2). Through surveying students, the NSSE assesses students' engagement in “. . . educational practices associated with high levels of learning and development" (NSSE, 2006, p.2). The NSSE then disseminates the information gathered in order to help institutions of higher education improve and increase student learning. The results are compiled into five national benchmark scores and are then compared to national mean scores. 
The five benchmarks of effective educational practice associated with high levels of learning and development are:

1. Level of Academic Challenge (NSSE \# 1r, 2b, 2c, 2d, 2e, 3a, 3c, 3d, 3e, 9a, 10a)

2. Active and Collaborative Learning (NSSE \# 1a, 1b, 1g, 1h, 1j, 1k, $1 \mathrm{t}$ )

3. Student-Faculty Interaction (NSSE \# 1n, 1o, 1p, 1q, 1s, 7d)

4. Enriching Educational Experiences (NSSE \# 11, 1u, 1v, 7a, 7b, 7c, 7e, 7f, 7g, 7h, $9 \mathrm{~d}, 10 \mathrm{c})$

5. Supportive Campus Environment (NSSE \# 8a, 8b, 8c, 10b, 10d, 10e)

The NSSE uses a series of questions scored on a Likert scale to evaluate these benchmarks. "The benchmarks are based on 42 questions from the NSSE survey that capture many vital aspects of the student experience... [which] are some of the more powerful contributors to learning and personal development" (NSSE, 2011). Level of Academic Challenge consists of eleven questions. Active and Collaborative Learning consists of seven questions. Student-Faculty Interaction consists of six questions. Enriching Educational Experiences consist of twelve questions. Supportive Campus Environment consists of six questions. A copy of the 2009 NSSE instrument, The College Student Report, appears in Appendix A.

\section{Validity and Reliability}

The NSSE uses student self-reports to determine the quality of the undergraduate experience. According to Kuh (2001), if certain conditions are met, then self-reported data are likely to be valid, and, "[NSSE] was designed accordingly" (p. 13). Kuh et al. (2007) posit that "if survey data are used for institutional decision making, improvement, and public accountability, it is imperative that the data collection tools be valid and 
reliable" (p. 39). In their Connecting the Dots Report (2007), Kuh et al. state that a series of analyses were conducted to determine “...how the NSSE survey performs when completed by minority students at PWIs as well as at Minority Serving Institutions, relative to other types of institutional settings" and assert that "... a combination of statistical analyses and qualitative methods were used to examine the validity, reliability, and other psychometric properties of the NSSE survey for different types of students and institutions" (p. 6). Additionally, a majority of items on the NSSE have been assessed in other long-standing surveys including the Cooperative Institutional Research Program, which was “established in 1966... and is now the nation's largest and oldest empirical study of higher education..." (heri.com, 2011) and the College Student Experiences Questionnaire (Pace, 1984). Over time, these surveys have been confirmed to measure what they purport to measure and the results have been consistent. Thus, validity and reliability of the NSSE have been established through formal research studies.

\section{Specific Description of Data Analysis}

In this section, the specific types of data analysis are discussed. First the researcher provided descriptive statistics by analyzing the frequencies and percentages derived from the demographic data contained within the NSSE. Demographic information was coded into eight categories as follows:

1. Gender

2. College

3. Citizenship

4. Enrollment

5. Fraternity/Sorority Membership 
6. Living Situation

7. Parents' Level of Education

8. Cumulative GPA

This information provided important background information about the participants in this dissertation research study.

Each research question is linked with specific survey items within the NSSE (see Table 1).

T-tests within the Statistical Package for the Social Sciences (SPSS) 17.0 were used for analyzing the information related to each of the research questions. T-tests revealed if there were statistically significant differences in gender, Greek organization membership, parents' level of education, student interaction with faculty, co-curricular involvement, and NSSE scores.

Research Question 1: Is there a statistically significant difference between the levels of college engagement for successful Black female students and successful Black male students?

The t-test was utilized to determine if there was a statistically significant difference in student engagement (Level of Academic Challenge, Active and Collaborative Learning, Student-Faculty Interaction, Enriching Educational Experiences, Supportive Campus Environment) with the gender (male versus female) of successful undergraduate Black commuter students. Gender served as the independent variable, and the dependent variables were the five areas of student engagement determined by the responses on the NSSE.

Research Question 2: Is there a statistically significant difference between the 
levels of college engagement for successful Black fraternity and sorority members and successful non-members?

The t-test test was utilized to determine if there was a statistically significant difference in student engagement (Level of Academic Challenge, Active and Collaborative Learning, Student-Faculty Interaction, Enriching Educational Experiences, Supportive Campus Environment) with the Greek letter membership (member versus non-member) of successful undergraduate Black commuter students. Greek letter membership served as the independent variable, and the dependent variables were the five areas of student engagement determined by the responses on the NSSE.

Research Question 3: Is there a statistically significant difference between the levels of college engagement for successful students whose parents completed a college degree (at least one parent with an associate's degree or higher) and successful students whose parents did not complete a college degree (both parents attended college but did not complete a degree or lower)?

The t-test was utilized to determine if there is a statistically significant difference in student engagement (Level of Academic Challenge, Active and Collaborative Learning, Student-Faculty Interaction, Enriching Educational Experiences, Supportive Campus Environment) with parents' educational attainment (college degree versus no college degree) of successful undergraduate Black commuter students. Parents' educational attainment served as the independent variable, and the dependent variables were the five areas of student engagement determined by the responses on the NSSE.

Research Question 4: Is there a statistically significant difference between the levels of college engagement for successful Black students who interact with faculty often and 
not-often?

The t-test was utilized to determine if there was a statistically significant difference in student engagement (Level of Academic Challenge, Active and Collaborative Learning, Enriching Educational Experiences, Supportive Campus Environment) with faculty interaction (frequent interaction versus infrequent interaction) of successful undergraduate Black commuter students. Faculty interaction served as the independent variable, and the dependent variables were four of the five areas of student engagement determined by the responses on the NSSE.

Research Question 5: Is there a statistically significant difference between the levels of college engagement for successful Black students who participate in cocurricular activities often (16 or more hours) and those who do not (15 or less hours)?

The t-test was utilized to determine if there was a statistically significant difference in student engagement (Level of Academic Challenge, Active and Collaborative Learning, Student-Faculty Interaction, Supportive Campus Environment) with co-curricular participation (frequent participation versus infrequent participation) of successful undergraduate Black commuter students. Co-curricular participation served as the independent variable, and the dependent variables were four of the five areas of student engagement determined by the responses on the NSSE. 
Table 1

Connections between Research Questions and Survey Items

\begin{tabular}{|c|c|}
\hline \multicolumn{2}{|c|}{ Research Questions and Survey Items } \\
\hline Research Question & Survey Item \\
\hline $\begin{array}{l}\text { Is there a statistically significant } \\
\text { difference between the levels of college } \\
\text { engagement for successful } \\
\text { Black female students and successful } \\
\text { Black male students? }\end{array}$ & $\begin{array}{l}16 \rightarrow \text { LAC (survey \# 1r, 2b, 2c, 2d, 2e, 3a, 3c, 3d, } \\
3 \mathrm{e}, 9 \mathrm{a}, 10 \mathrm{a}) \\
16 \rightarrow \text { ACL (survey \# 1a, 1b, 1g, 1h, 1j, 1k, 1 t) } \\
16 \rightarrow \text { SFI (survey \# 1n, 1o, 1p, 1q, 1s, 7d) } \\
16 \rightarrow \text { EEE (survey \# 11, 1u, 1v, 7a, 7b, 7c, 7e, 7f, } \\
7 \mathrm{~g}, 7 \mathrm{~h}, 9 \mathrm{~d}, 10 \mathrm{c} \text { ) } \\
16 \rightarrow \text { SCE (survey \# 8a, 8b, 8c, 10b, 10d, 10e) }\end{array}$ \\
\hline $\begin{array}{l}\text { 2. Is there a statistically significant } \\
\text { difference between the levels of college } \\
\text { engagement for successful Black } \\
\text { fraternity and sorority members and } \\
\text { successful non-members? }\end{array}$ & $\begin{array}{l}23 \rightarrow \text { LAC (survey \# 1r, 2b, 2c, 2d, 2e, 3a, 3c, 3d, } \\
3 \mathrm{e}, \\
9 \mathrm{a}, 10 \mathrm{a}) \\
23 \rightarrow \text { ACL (survey \# 1a, 1b, 1g, 1h, 1j, 1k, } 1 \mathrm{t} \text { ) } \\
23 \rightarrow \text { SFI (survey \# 1n, 1o, 1p, 1q, 1s, 7d) } \\
23 \rightarrow \text { EEE (survey \# 1l, 1u, 1v, 7a, 7b, 7c, 7e, 7f, } \\
7 \mathrm{~g}, 7 \mathrm{~h}, 9 \mathrm{~d}, 10 \mathrm{c}) \\
23 \rightarrow \text { SCE (survey \# 8a, 8b, 8c, 10b, 10d, 10e) }\end{array}$ \\
\hline $\begin{array}{l}\text { 3. Is there a statistically significant } \\
\text { difference between the levels of college } \\
\text { engagement for successful students } \\
\text { whose parents completed a college } \\
\text { degree (at least one parent with an } \\
\text { associate's degree or higher) and } \\
\text { successful students whose parents did } \\
\text { not complete a college degree (both } \\
\text { parents attended college but did not } \\
\text { complete a degree or lower)? }\end{array}$ & $\begin{array}{l}27 \rightarrow \text { LAC (survey \# 1r, 2b, 2c, 2d, 2e, 3a, 3c, 3d, } \\
3 \mathrm{e}, \\
9 \mathrm{a}, 10 \mathrm{a}) \\
27 \rightarrow \text { ACL (survey \# 1a, 1b, 1g, 1h, 1j, 1k, } 1 \mathrm{t} \text { ) } \\
27 \rightarrow \text { SFI (survey \# 1n, 1o, 1p, 1q, 1s, 7d) } \\
27 \rightarrow \text { EEE (survey \# 11, 1u, 1v, 7a, 7b, 7c, 7e, 7f, } \\
7 \mathrm{~g}, 7 \mathrm{~h}, 9 \mathrm{~d}, 10 \mathrm{c}) \\
27 \rightarrow \text { SCE (survey \# 8a, 8b, 8c, 10b, 10d, 10e) }\end{array}$ \\
\hline $\begin{array}{l}\text { 4. Is there a statistically significant } \\
\text { difference between the levels of college } \\
\text { engagement for successful Black } \\
\text { students who interact with faculty often } \\
\text { and not-often? }\end{array}$ & $\begin{array}{l}1(\mathrm{n}, \mathrm{o}, \mathrm{p}, \mathrm{q}, \mathrm{s}) \rightarrow \mathrm{LAC}(\text { survey \# 1r, 2b, 2c, 2d, 2e, } \\
3 \mathrm{a}, 3 \mathrm{c}, 3 \mathrm{~d}, 3 \mathrm{e}, 9 \mathrm{a}, 10 \mathrm{a}) \\
1(\mathrm{n}, \mathrm{o}, \mathrm{p}, \mathrm{q}, \mathrm{s}) \rightarrow \text { ACL (survey \# 1a, 1b, 1g, 1h, 1j, } \\
1 \mathrm{k}, 1 \mathrm{t}) \\
1(\mathrm{n}, \mathrm{o}, \mathrm{p}, \mathrm{q}, \mathrm{s}) \rightarrow \text { EEE (survey \# 11, 1u, 1v, 7a, 7b, } \\
7 \mathrm{c}, 7 \mathrm{e}, 7 \mathrm{f}, 7 \mathrm{~g}, 7 \mathrm{~h}, 9 \mathrm{~d}, 10 \mathrm{c}) \\
1(\mathrm{n}, \mathrm{o}, \mathrm{p}, \mathrm{q}, \mathrm{s}) \rightarrow \text { SCE (survey \# 8a, 8b, 8c, 10b, } \\
10 \mathrm{~d}, 10 \mathrm{e})\end{array}$ \\
\hline
\end{tabular}

(continued) 
Table 1 (continued)

5. Is there a statistically significant difference between the levels of college engagement for successful Black students who participate in co-curricular activities often (16 or more hours) and those who do not (15 or less hours)?

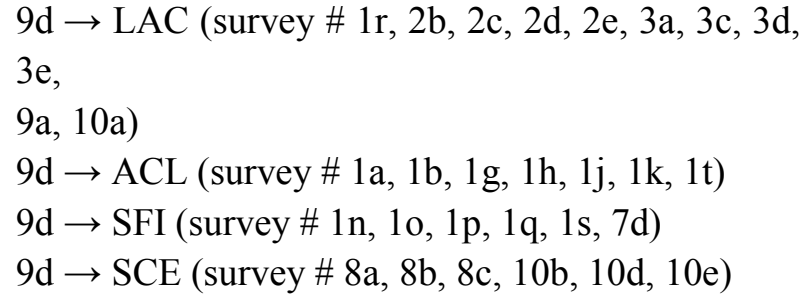

Key

LAC: Level of Academic Challenge

ACL: Active and Collaborative Learning

SFI: Student-Faculty Interaction

EEE: Enriching Educational Experiences

SCE: Supportive Campus Environment

\section{Limitations of the Study}

There are a number of limitations associated with this study. First, this particular study uses self-reported data, therefore, the study is limited by the accuracy of the respondents' self-perceptions. Second, in this particular study, students from CUNY constituted the population to determine what influences successful Black students' levels of engagement. Care needs to be taken when generalizing this sample to the larger population. In addition, the focus was on commuter students who may have different college experiences from full-time students who live on campus. Third, the NSSE instrument is relatively short and does not measure all the relevant aspects of engagement. Fourth, according to CUNY (2011c), more female students are enrolled $(58.6 \%)$ than male students $(41.4 \%)$. Fifth, the researcher assumes that the students included in this study are graduating. Finally, although this study can be applied to CUNY, it may not be applicable to universities within the State University of New York, HBCU's or other institutions of higher education. 


\section{CHAPTER FOUR}

\section{Results and Discussion}

\section{Overview}

This chapter presents the results of the survey research. First, an overview of the survey process is provided. Second, the student demographic information is presented. Finally, the data are discussed according to each research question.

Research questions. Each research question examines levels of engagement among successful Black students. Success is defined as Black, senior students who have maintained at least a $\mathrm{C}$ overall grade point average (GPA) at CUNY. Research question one examines if there is a significant difference between the levels of college engagement for successful Black students by gender (male versus female). Research question two examines if there is a significant difference between the levels of college engagement for successful Black students by fraternity/sorority membership (member versus nonmember). Research question three examines if there is a significant difference between the levels of college engagement for successful Black students by parents' educational attainment. Students whose parents achieved an associate's degree or higher were collapsed into the "yes" category. Students whose parents did not receive a degree were collapsed into the "no" category. Research question four examines if there is a significant difference between the levels of college engagement for successful Black students by their interaction with faculty. Students who reported that they had high levels of interaction with faculty (very often, often, done, plan to do) were placed in the "often" category. Students who reported that they had low levels of interaction with faculty (sometimes, never, do not plan to do, have not decided) were placed in the "not often" 
category. Research question five examines if there is a significant difference between the levels of college engagement for successful Black students by participation in cocurricular activities. Students who reported spending 16 or more hours a week participating in co-curricular activities were placed in the "often" category. Students who reported spending 15 hours or less hours a week participating in co-curricular activities were placed in the "not often" category.

\section{Survey Process}

The researcher analyzed the existing data CUNY had collected from their undergraduates who completed the NSSE in 2009. Two hundred eighty student survey responses were analyzed according to the procedures discussed in chapter three.

\section{Missing Data}

Cases were included in the current dissertation study if study participants met all inclusion criteria described previously, as well as providing $80 \%$ of data on each scale examining engagement. A careful analysis indicated that 280 student participants (approximately $45 \%$ of Black students surveyed) met the inclusion criteria for this study. When study participants provided at least $80 \%$ of data, but did not respond to all scale items, the mean score value was used for the items they did respond to.

\section{Measurements}

As previously stated, the NSSE identifies five benchmarks of effective educational practice associated with high levels of learning and development. A multidimensional construct of engagement was created by establishing one scale for each of the five benchmarks. 
Level of Academic Challenge. The LAC scale is comprised of eleven items (see Table 2). One item (1r) is measured on a 1 to 4 Likert-type scale ( $1=$ Never to $4=$ Very Often). Five items (2b, 2c, 2d, 2e, 10a) are measured on a 1 to 4 Likert-type scale (1=Very Little to $4=$ Very Much). To conduct the appropriate analyses, all questions need to consistently have four response groupings.

Item 3a originally consisted of five different responses regarding the number of assigned textbooks/readings that were 20 pages or more (more than 20 assigned textbooks/readings read, 11-20 assigned textbooks/readings read, 5-10 assigned textbooks/readings read, 1-4 assigned textbooks/readings read, no assigned textbooks/readings read). These five response categories were collapsed into four response categories. The first category became none- 4 assigned textbooks/readings read (no assigned textbooks/readings read was combined with 1-4 assigned textbooks/readings read category). The second category became 5-10 assigned textbooks/readings read. The third category became 11-20 assigned textbooks/readings read. The fourth category became more than 20 assigned textbooks/readings read.

Item $3 c$ originally consisted of five different responses regarding the number of written papers/reports that were 20 or more pages (wrote more than 20 papers, wrote 1120 papers, wrote 5-10 papers, wrote 1-4 papers, wrote no papers). These five response categories were collapsed into four response categories. The first category remained "none" because there were no papers written. The second category remained 1-4 papers written. The third category remained 5-10 papers written. The fourth category became 11 to more than 20 papers written (11-20 papers written was combined with more than 20 papers written category). 
Item $3 \mathrm{~d}$ originally consisted of five different responses regarding the number of written papers/reports that were between 5 and 19 pages (wrote more than 20 papers, wrote 11-20 papers, wrote 5-10 papers, wrote 1-4 papers, wrote no papers). These five response categories were collapsed into four response categories. The first category remained "none". The second category remained 1-4 papers written. The third category remained 5-10 papers written. The fourth category became 11 to more than 20 papers written (11-20 papers written was combined with more than 20 papers written category). Item 3e originally consisted of five different responses regarding the number of written papers/reports that were fewer than 5 pages (wrote more than 20 papers, wrote 11-20 papers, wrote 5-10 papers, wrote 1-4 papers, wrote no papers). These five response categories were collapsed into four response categories. The first category remained "none". The second category remained 1-4 papers written. The third category remained 5-10 papers written. The fourth category became 11 to more than 20 papers written (1120 papers written was combined with more than 20 papers written).

Item 9 a originally had 8 different potential responses regarding number of hours spent preparing for class (more than 30 hours, 26-30 hours, 21-25 hours, 16-20 hours, 1115 hours, 6-10 hours, $1-5$ hours, 0 hours). The first category became $0-5$ hours ( 0 hours combined with 1-5 hours category). The second category became 6-10 hours. The third category became 11-20 hours (11-15 hours combined with 16-20 hours category). The fourth category became 21 to more than 30 hours (21-25 was combined with the 26-30 hours and with the more than 30 hours categories). 
The LAC scale was computed by calculating the mean of all eleven items thereby producing a single mean score. A reliability analysis indicated a satisfactory level of internal consistency $($ Cronbach's alpha $=.69)$. 
Table 2

Level of Academic Challenge (LAC)

\begin{tabular}{|c|c|c|c|c|}
\hline Item & $\begin{array}{l}\text { Very often or } \\
\text { Very much }(4)\end{array}$ & $\begin{array}{l}\text { Often or } \\
\text { Quite a bit (3) }\end{array}$ & $\begin{array}{l}\text { Sometimes or } \\
\text { Some }(2)\end{array}$ & $\begin{array}{l}\text { Never or } \\
\text { Very little }(1)\end{array}$ \\
\hline
\end{tabular}

(1r) Worked harder to meet
instructor's standards or

$\begin{array}{llll}n & n & \%\end{array}$

40.7

88

31.4

12

expectations

(2b) Coursework emphasized analyzing

141

elements of idea

(2c) Coursework emphasized synthesizing

23.6

114

40.7

88

12

ideas or information

(2d) Coursework

emphasized making

94

33.6

36.1

37 4

judgments

2e) Coursework

102

36.4

enplying

emphasizes spending

significant time studying

and academic work 
Table 2 (continued)

\begin{tabular}{|c|c|c|c|c|c|c|c|c|}
\hline$\overline{\text { Item }}$ & & & & & & & & \\
\hline & $\begin{array}{l}\text { Mo } \\
\text { or } \mathrm{r}\end{array}$ & extbooks & & & $\begin{array}{l}5-10 \\
\text { or re }\end{array}$ & & $\begin{array}{l}\text { None- } \\
\text { or reac }\end{array}$ & $\begin{array}{l}\text { books } \\
\text { (1) }\end{array}$ \\
\hline & $n$ & $\%$ & $n$ & $\%$ & $n$ & $\%$ & $n$ & $\%$ \\
\hline $\begin{array}{l}\text { (3a) Number of } \\
\text { assigned textbooks }\end{array}$ & 58 & 20.7 & 57 & 20.4 & 94 & 33.6 & 71 & 25.4 \\
\hline Item & & & & & & & & \\
\hline & $\begin{array}{l}11-1 \\
\text { wri }\end{array}$ & & $\begin{array}{l}5-1 \\
w r i\end{array}$ & & $\begin{array}{l}1-4 \\
\text { writt }\end{array}$ & $s(2)$ & $\begin{array}{l}\text { None/1 } \\
\text { writter }\end{array}$ & rs (1) \\
\hline & $n$ & $\%$ & $n$ & $\%$ & $n$ & $\%$ & $n$ & $\%$ \\
\hline $\begin{array}{l}\text { (3c) Number of } \\
\text { papers } 20 \text { or more pages }\end{array}$ & 11 & 3.9 & 22 & 7.9 & 97 & 34.8 & 149 & 53.4 \\
\hline $\begin{array}{l}\text { (3d) Number of } \\
\text { papers 5-19 pages }\end{array}$ & 39 & 14.1 & 86 & 31.0 & 123 & 44.4 & 29 & 10.5 \\
\hline $\begin{array}{l}(3 \mathrm{e}) \text { Number of } \\
\text { papers fewer than } 5 \\
\text { pages }\end{array}$ & 64 & 23.4 & 51 & 18.6 & 122 & 44.5 & 37 & 13.5 \\
\hline Item & & & & & & & & \\
\hline & $\begin{array}{l}21-1 \\
\text { hou }\end{array}$ & & $\begin{array}{l}11 \\
\text { hot }\end{array}$ & & $\begin{array}{l}6-1 \\
\text { hou }\end{array}$ & & $\begin{array}{l}0-5 \\
\text { hou }\end{array}$ & \\
\hline & $n$ & $\%$ & $n$ & $\%$ & $n$ & $\%$ & $n$ & $\%$ \\
\hline $\begin{array}{l}\text { (9a) Number of } \\
\text { hours spent preparing for } \\
\text { class }\end{array}$ & 44 & 15.8 & 88 & 31.5 & 66 & 23.7 & 81 & 29.0 \\
\hline
\end{tabular}


Active and Collaborative Learning. The ACL scale is comprised of 7 items (see Table 3). All 7 items (1a, 1b, 1g, 1h, 1j, 1k, 1t) are measured on a 1 to 4 Likert-type scale ( $1=$ Never to $4=$ Very Often). The ACL scale was computed by calculating the mean of all seven items thereby producing a single mean score. A reliability analysis indicated a satisfactory level of internal consistency (Cronbach's alpha $=.73)$. 
Table 3

\section{Active and Collaborative Learning (ACL)}

\begin{tabular}{|c|c|c|c|c|c|c|c|c|}
\hline \multirow[t]{2}{*}{ Item } & \multicolumn{2}{|c|}{ Very often (4) } & \multicolumn{2}{|c|}{ Often (3) } & \multicolumn{2}{|c|}{ Sometimes (2) } & \multicolumn{2}{|c|}{ Never (1) } \\
\hline & $n$ & $\%$ & $n$ & $\%$ & $n$ & $\%$ & $n$ & $\%$ \\
\hline $\begin{array}{l}\text { (1a) Asked questions or } \\
\text { contributed to discussion }\end{array}$ & 121 & 43.5 & 86 & 30.9 & 66 & 23.7 & 5 & $\overline{1.8}$ \\
\hline (1b) Made class presentation & 66 & 23.8 & 97 & 35.0 & 99 & 35.7 & 15 & 5.4 \\
\hline $\begin{array}{l}\text { (1g) Worked with other } \\
\text { students DURING class }\end{array}$ & 57 & 20.7 & 95 & 34.4 & 106 & 38.4 & 18 & 6.5 \\
\hline $\begin{array}{l}\text { (1h) Worked with other } \\
\text { students OUTSIDE class }\end{array}$ & 56 & 20.0 & 77 & 27.5 & 118 & 42.1 & 29 & 10.4 \\
\hline $\begin{array}{l}\text { (1j) Tutored/taught other } \\
\text { students (paid/volunteer) }\end{array}$ & 22 & 7.9 & 21 & 7.5 & 84 & 30.0 & 153 & 54.6 \\
\hline $\begin{array}{l}\text { (1k) Participate in community- } \\
\text { based learning as part of course }\end{array}$ & 21 & 7.6 & 13 & 4.7 & 68 & 24.5 & 176 & 63.3 \\
\hline $\begin{array}{l}\text { (1t) Discussed ideas from } \\
\text { readings/classes with others } \\
\text { outside of class }\end{array}$ & 91 & 32.5 & 87 & 31.2 & 90 & 32.3 & 11 & 3.9 \\
\hline
\end{tabular}


Student-Faculty Interaction. The SFI scale is comprised of 6 items (see Table 4). Five items (1n, 1o, 1p, 1q, 1s) are measured on a 1 to 4 Likert-type scale (1=Never to 4 =Very Often). One item ( $7 \mathrm{~d})$ is measured on a 1 to 4 Likert-type scale ( $1=$ Have not decided to 4=Done). The SFI scale was computed by calculating the mean of all six items thereby producing a single mean score. A reliability analysis indicated a satisfactory level of internal consistency (Cronbach's alpha $=.71)$. 
Table 4

\section{Student Faculty Interaction (SFI)}

\begin{tabular}{|c|c|c|c|c|c|c|c|c|}
\hline \multirow[t]{2}{*}{ Item } & \multicolumn{2}{|c|}{$\begin{array}{l}\text { Very often or } \\
\text { Done }(4)\end{array}$} & \multicolumn{2}{|c|}{$\begin{array}{l}\text { Often or } \\
\text { Plan to do (3) }\end{array}$} & \multicolumn{2}{|c|}{$\begin{array}{l}\text { Sometimes or } \\
\text { Do not plan to do (2) }\end{array}$} & \multicolumn{2}{|c|}{$\begin{array}{c}\text { Never or } \\
\text { Have not decided (1) }\end{array}$} \\
\hline & $n$ & $\%$ & $n$ & $\%$ & $n$ & $\%$ & $n$ & $\%$ \\
\hline $\begin{array}{l}\text { (1n) Discussed grades or } \\
\text { assignments with instructor }\end{array}$ & 79 & 28.3 & 93 & 33.3 & 95 & 34.1 & 12 & 4.3 \\
\hline $\begin{array}{l}\text { (1o) Talked about career } \\
\text { plans with faculty member } \\
\text { or advisor }\end{array}$ & 44 & 15.7 & 55 & 19.6 & 127 & 45.4 & 54 & 19.3 \\
\hline $\begin{array}{l}\text { ( } 1 \mathrm{p}) \text { Discussed ideas from } \\
\text { readings or classes with } \\
\text { faculty members outside } \\
\text { of class }\end{array}$ & 20 & 7.1 & 54 & 19.3 & 120 & 42.9 & 86 & 30.7 \\
\hline $\begin{array}{l}\text { (1q) Received prompt written } \\
\text { or oral feedback from faculty } \\
\text { on academic performance }\end{array}$ & 56 & 20.3 & 104 & 37.7 & 86 & 31.2 & 30 & 10.9 \\
\hline $\begin{array}{l}\text { (1s) Worked with faculty on } \\
\text { activities other than } \\
\text { coursework }\end{array}$ & 15 & 5.4 & 29 & 10.5 & 80 & 29.0 & 152 & 55.1 \\
\hline $\begin{array}{l}(7 \mathrm{~d}) \text { Work on a research } \\
\text { project with faculty outside } \\
\text { of course or program } \\
\text { requirements }\end{array}$ & 44 & 15.9 & 45 & 16.2 & 100 & 36.1 & 88 & 31.8 \\
\hline
\end{tabular}


Enriching Educational Experiences. The EEE scale is comprised of 12 items (see Table 5). Three items (11, 1u, 1v) are measured on a 1 to 4 Likert-type scale $(1=$ Never to $4=$ Very Often). Seven items $(7 \mathrm{a}, 7 \mathrm{~b}, 7 \mathrm{c}, 7 \mathrm{e}, 7 \mathrm{f}, 7 \mathrm{~g}, 7 \mathrm{~h})$ are measured on a 1 to 4 Likert-type scale (1=Have not decided to $4=$ Done). To conduct the appropriate analyses, all questions need to consistently have four response groupings.

Item $9 \mathrm{~d}$ originally had 8 different potential responses regarding number of hours spent participating in co-curricular activities (more than 30 hours, 26-30 hours, 21-25 hours, 16-20 hours, 11-15 hours, 6-10 hours, 1-5 hours, 0 hours). The first category remained 0 hours. The second category remained 1-5 hours. The third category remained 6-10 hours. The fourth category became 11 to more than 30 hours (11-15 hours was combined with the 16-20 hours, 21-25 hours, 26-30 hours and with the more than 30 hours categories).

One item (10c) is measured along a 1 to 4 Likert-type scale (1=Very Little to 4 =Very Much). The EEE scale was computed by calculating the mean of all twelve items thereby producing a single mean score. A reliability analysis indicated a satisfactory level of internal consistency (Cronbach's alpha $=.69$ ). 
Table 5

\section{Enriching Educational Experiences (EEE)}

\begin{tabular}{|c|c|c|c|c|c|c|c|c|}
\hline \multirow[t]{2}{*}{$\overline{\text { Item }}$} & \multicolumn{2}{|c|}{$\begin{array}{l}\text { Very often or } \\
\text { Done or } \\
\text { Very much (4) }\end{array}$} & \multicolumn{2}{|c|}{$\begin{array}{l}\text { Often or } \\
\text { Plan to do or } \\
\text { Quite a bit (3) }\end{array}$} & \multicolumn{2}{|c|}{$\begin{array}{l}\text { Sometimes or } \\
\text { Do not plan to do or } \\
\text { Some }(2)\end{array}$} & \multicolumn{2}{|c|}{$\begin{array}{c}\text { Never or } \\
\text { Have not decided or } \\
\text { Very little }(1)\end{array}$} \\
\hline & $n$ & $\%$ & $n$ & $\%$ & $n$ & $\%$ & $n$ & $\%$ \\
\hline $\begin{array}{l}\text { (11) Used an electronic } \\
\text { medium to discuss or } \\
\text { complete an assignment }\end{array}$ & 80 & 28.6 & 89 & 31.8 & 78 & 27.9 & 33 & 11.8 \\
\hline (1u) Had serious & & & & & & & & \\
\hline $\begin{array}{l}\text { conversations with students } \\
\text { of a different race/ethnicity }\end{array}$ & 96 & 34.5 & 78 & 28.1 & 78 & 28.1 & 26 & 9.4 \\
\hline $\begin{array}{l}\text { (1v) Had serious } \\
\text { conversations with students } \\
\text { who have different } \\
\text { beliefs/values }\end{array}$ & 91 & 32.6 & 66 & 23.7 & 86 & 30.8 & 37 & 12.9 \\
\hline $\begin{array}{l}\text { (7a) Practicum, intern, } \\
\text { field experience, co-op } \\
\text { experience, clincals }\end{array}$ & 117 & 42.5 & 83 & 30.2 & 38 & 13.8 & 37 & 13.5 \\
\hline $\begin{array}{l}\text { ( } 7 \mathrm{~b}) \text { Community service } \\
\text { or volunteer work }\end{array}$ & 121 & 43.4 & 85 & 30.5 & 31 & 11.1 & 42 & 15.1 \\
\hline
\end{tabular}


Table 5 (continued)

\begin{tabular}{|c|c|c|c|c|c|c|c|c|}
\hline \multirow[t]{2}{*}{ Item } & \multicolumn{2}{|c|}{$\begin{array}{l}\text { Very often or } \\
\text { Done or } \\
\text { Very much (4) }\end{array}$} & \multicolumn{2}{|c|}{$\begin{array}{l}\text { Often or } \\
\text { Plan to do or } \\
\text { Quite a bit (3) }\end{array}$} & \multicolumn{2}{|c|}{$\begin{array}{l}\text { Sometimes or } \\
\text { Do not plan to do or } \\
\text { Some (2) }\end{array}$} & \multicolumn{2}{|c|}{$\begin{array}{c}\text { Never or } \\
\text { Have not decided or } \\
\text { Very little (1) }\end{array}$} \\
\hline & $n$ & $\%$ & $n$ & $\%$ & $n$ & $\%$ & $n$ & $\%$ \\
\hline $\begin{array}{l}\text { (7e) Foreign language } \\
\text { coursework }\end{array}$ & 108 & 38.8 & 36 & 12.9 & 80 & 28.8 & 54 & 19.4 \\
\hline (7f) Study abroad & 17 & 6.1 & 39 & 14.0 & 146 & 52.3 & 77 & 27.6 \\
\hline $\begin{array}{l}(7 \mathrm{~g}) \text { Independent study } \\
\text { or self-designed major }\end{array}$ & 43 & 15.5 & 36 & 12.9 & 129 & 46.4 & 70 & 25.2 \\
\hline $\begin{array}{l}\text { (7h) Culminating } \\
\text { senior experience }\end{array}$ & 60 & 21.4 & 90 & 32.1 & 59 & 21.1 & 71 & 25.4 \\
\hline $\begin{array}{l}(10 \mathrm{c}) \text { Encouraging } \\
\text { contact among diverse } \\
\text { students }\end{array}$ & 85 & 30.4 & 74 & 26.4 & 64 & 22.9 & 57 & 20.4 \\
\hline \multicolumn{9}{|l|}{$\overline{\text { Item }}$} \\
\hline & \multicolumn{2}{|c|}{$\begin{array}{l}11-30 \text { or more hours } \\
\text { (4) }\end{array}$} & \multicolumn{2}{|c|}{$\begin{array}{l}\text { 6-10 hours } \\
\text { (3) }\end{array}$} & \multicolumn{2}{|c|}{$\begin{array}{l}1-5 \text { hours } \\
\text { (2) }\end{array}$} & \multicolumn{2}{|c|}{$\begin{array}{l}0 \text { hours } \\
\text { (1) }\end{array}$} \\
\hline & $n$ & $\%$ & $n$ & $\%$ & $n$ & $\%$ & $n$ & $\%$ \\
\hline $\begin{array}{l}\text { (9d) Number of hours } \\
\text { spent participating } \\
\text { in co-curricular } \\
\text { activities }\end{array}$ & 21 & 7.5 & 19 & 6.8 & 54 & 19.3 & 186 & 66.4 \\
\hline
\end{tabular}


Supportive Campus Environment. The SCE scale is comprised of 6 items (see Table 6). To conduct the appropriate analyses, all questions need to consistently have four response groupings.

Item 8 a originally consisted of seven different responses to rate the quality of relationships with other students (friendly, supportive, sense of belonging to unfriendly, unsupportive, sense of alienation). These seven response categories were collapsed into four response categories. The first category became 1 (ratings of 1, 2, 3, and 4 were combined) meaning that students were unfriendly. The second category became 2 (rating 5). The third category became 3 (rating 6). The fourth category became 4 (rating 7) meaning that students were friendly.

Item $8 \mathrm{~b}$ originally consisted of seven different responses to rate the quality of relationships with faculty (available, helpful, sympathetic to unavailable, unhelpful, unsympathetic). These seven response categories were collapsed into four response categories. The first category became 1 (ratings of 1, 2, 3, and 4 were combined) meaning that faculty were less supportive. The second category became 2 (rating 5). The third category became 3 (rating 6). The fourth category became 4 (rating 7) meaning that faculty were very supportive.

Item $8 \mathrm{c}$ originally consisted of seven different responses to rate the quality of relationships with administrative personnel and offices (helpful, considerate, flexible to unhelpful, inconsiderate, rigid). These seven response categories were collapsed into four response categories. The first category became 1 (ratings of 1, 2, and 3 were combined) meaning that administrative personnel and offices were less helpful. The second category became 2 (rating 4). The third category became 3 (rating 5). The fourth 
category became 4 (ratings 6 and 7 were combined) meaning that administrative personnel and offices helpful.

Three items $(10 \mathrm{~b}, 10 \mathrm{~d}, 10 \mathrm{e})$ are measured on a 1 to 4 Likert-type scale (1=Very Little to 4 =Very Much). The SCE scale was computed by calculating the mean of all six items thereby producing a single mean score. A reliability analysis indicated a satisfactory level of internal consistency (Cronbach's alpha $=.78)$. 
Table 6

Supportive Campus Environment (SCE)

\begin{tabular}{|c|c|c|c|c|c|c|c|c|}
\hline \multirow[t]{2}{*}{ Item } & \multicolumn{2}{|c|}{$\begin{array}{l}\text { Helpful, friendly, } \\
\text { or supportive } \\
\text { (4) }\end{array}$} & \multicolumn{2}{|l|}{ (3) } & \multicolumn{2}{|l|}{ (2) } & \multicolumn{2}{|c|}{$\begin{array}{c}\text { Unhelpful, } \\
\text { unfriendly, or } \\
\text { unsupportive (1) }\end{array}$} \\
\hline & $n$ & $\%$ & $n$ & $\%$ & $n$ & $\%$ & $n$ & $\%$ \\
\hline $\begin{array}{l}\text { (8a) Quality of } \\
\text { relationship with students }\end{array}$ & 85 & 29.3 & 60 & 21.4 & 63 & 22.5 & 75 & 26.8 \\
\hline $\begin{array}{l}\text { (8b) Quality of } \\
\text { relationship with faculty }\end{array}$ & 54 & 19.4 & 63 & 22.6 & 77 & 27.6 & 85 & 30.4 \\
\hline $\begin{array}{l}\text { (8c) Quality of } \\
\text { relationship with } \\
\text { administrative personnel } \\
\text { and offices }\end{array}$ & 77 & 27.6 & 68 & 24.4 & 59 & 21.1 & 75 & 26.9 \\
\hline Item & $\begin{array}{l}\text { Ver } \\
n\end{array}$ & $\%$ & $\begin{array}{l}\text { Qui } \\
n\end{array}$ & $\%$ & $\begin{array}{l}\text { Son } \\
n\end{array}$ & $\%$ & $\begin{array}{l}\text { Ver } \\
n\end{array}$ & (1) $\%$ \\
\hline $\begin{array}{l}\text { (10b) Institution } \\
\text { emphasizes providing } \\
\text { academic support }\end{array}$ & 87 & 31.3 & 104 & 37.4 & 66 & 23.7 & 21 & 7.6 \\
\hline $\begin{array}{l}\text { (10d) Institution } \\
\text { emphasizes helping you } \\
\text { cope w/non-academic } \\
\text { responsibilities }\end{array}$ & 27 & 9.6 & 48 & 17.1 & 104 & 37.1 & 101 & 36.1 \\
\hline $\begin{array}{l}\text { (10e) Institution } \\
\text { emphasizes providing } \\
\text { social support }\end{array}$ & 37 & 13.4 & 55 & 19.9 & 103 & 37.3 & 81 & 29.3 \\
\hline
\end{tabular}


Composite. The composite scale is comprised of 42 items. The composite scale was computed by calculating the mean of all 42 items thereby producing a single mean score. A reliability analysis indicated a satisfactory level of internal consistency $($ Cronbach's alpha $=.89)$.

\section{Demographic Results}

At the end of the survey, CUNY students were asked to respond to series of items, which provided demographic data and frequencies on gender, college, citizenship, enrollment status, fraternity/sorority membership, living situation, parents' level of education, and cumulative GPA.

Gender. The majority (78\%) of participating students was female (see Table 7). According to CUNY, women make up 58.6\% of enrolled students (2011a). By gender, student respondents are not representative of the population; considerably fewer men responded to the NSSE given the CUNY population.

Table 7

Gender of Participating Students

\begin{tabular}{lcc}
\hline Gender & $n$ & $\%$ \\
\hline Female & 218 & $77.9 \%$ \\
Male & 62 & $22.1 \%$ \\
Total & 280 & $100 \%$ \\
\hline
\end{tabular}


College. In total, all 11 senior campuses within the CUNY system are represented. At least ten percent of students participated from each of the following colleges: Baruch, Brooklyn, College of Staten Island, Hunter, John Jay, and Medgar Evers (see Table 8).

Table 8

College of Participating Students

\begin{tabular}{lcc}
\hline CUNY College & $n$ & $\%$ \\
\hline Baruch College & 27 & $9.6 \%$ \\
Brooklyn College & 41 & $14.6 \%$ \\
City College of New York & 22 & $7.9 \%$ \\
College of Staten Island & 32 & $11.4 \%$ \\
Hunter College & 29 & $10.4 \%$ \\
John Jay College & 27 & $9.6 \%$ \\
Lehman College & 16 & $5.7 \%$ \\
Medgar Evers College & 37 & $13.2 \%$ \\
New York City College of Technology & 21 & $7.5 \%$ \\
Queens College & 15 & $5.4 \%$ \\
York College & 13 & $4.6 \%$ \\
Total & 280 & $100 \%$ \\
\hline
\end{tabular}


Citizenship. A large majority (79.9\%) of the participating students are citizens of the United States (see Table 9).

Table 9

U.S. Citizenship of Participating Students

\begin{tabular}{lcc}
\hline Citizen & $n$ & $\%$ \\
\hline Yes & 222 & $79.9 \%$ \\
No & 56 & $20.1 \%$ \\
Total & 278 & $100 \%$ \\
\hline
\end{tabular}

Enrollment status. A large majority (70.6\%) of participating students are enrolled full-time (see Table 10).

Table 10

Enrollment Status of Participating Students

\begin{tabular}{lcc}
\hline Enrollment Status & $n$ & $\%$ \\
\hline Full-time & 197 & $70.6 \%$ \\
Less than full-time & 82 & $29.4 \%$ \\
Total & 279 & $100 \%$ \\
\hline
\end{tabular}


Fraternity/Sorority membership. A large majority (93.5\%) of participating students are not members of a fraternity or sorority (see Table 11).

Table 11

Fraternity/Sorority Membership of Participating Students

\begin{tabular}{lll}
\hline Fraternity/Sorority Member & $n$ & $\%$
\end{tabular}

\begin{tabular}{lcc}
\hline Yes & 18 & $6.5 \%$ \\
No & 261 & $93.5 \%$ \\
Total & 279 & $100 \%$ \\
\hline
\end{tabular}

Living situation. A large majority (77.3\%) of participating students live within driving distance of their college (see Table 12).

Table 12

Living Situation of Participating Students

\begin{tabular}{lcc}
\hline Living Situation & \multicolumn{1}{l}{ n } & $\%$ \\
\hline Dormitory or other campus housing & 1 & $.4 \%$ \\
Residence within walking distance & 21 & $7.6 \%$ \\
Residence within driving distance & 214 & $77.3 \%$ \\
None of the above & 41 & $14.8 \%$ \\
Total & 277 & $100 \% *$ \\
\hline
\end{tabular}

*Rounding 
Parents' education. A majority of participating students' fathers $(69.8 \%)$ and mothers (68.5\%) did not earn a college degree (see Table 13).

Table 13

Parents' Level of Education of Participating Students

\begin{tabular}{llccc}
\hline Parents' Level of Education & Father & \multicolumn{3}{l}{ Mother } \\
& $n$ & $\%$ & $n$ & $\%$ \\
\hline Did not finish high school & 60 & 22.9 & 66 & 23.9 \\
Graduated from high school & 91 & 34.7 & 82 & 14.9 \\
Attended college: no degree & 32 & 12.2 & 41 & 10.5 \\
Associate's degree & 17 & 6.5 & 29 & 13.4 \\
Bachelor's degree & 36 & 13.7 & 37 & 7.2 \\
Master's degree & 21 & 8.0 & 20 & .4 \\
Doctoral degree (Ph.D., J.D., M.D., etc.) & 5 & 1.9 & 1 & $100 \%$ \\
\hline Total & 262 & $100 \%$ & 276 & \\
\hline
\end{tabular}


GPA. A majority (60\%) of participating students had overall GPA's in the B (B+, B, B-) range (see Table 14).

Table 14

GPA of Participating Students

\begin{tabular}{lcc}
\hline GPA & $n$ & $\%$ \\
\hline A & 46 & 16.4 \\
A- & 46 & 16.4 \\
B + & 63 & 22.5 \\
B & 75 & 26.8 \\
B- & 30 & 10.7 \\
C+ & 17 & 6.1 \\
C & 3 & 1.1 \\
Total & 280 & $100 \%$ \\
\hline
\end{tabular}

\section{Research Question 1}

The first research question was, "Is there a statistically significant difference between the levels of college engagement for successful Black female students and successful Black male students?" Data indicated that mean values did not vary at a statistically significant level between males and females regarding any of the engagement (Level of Academic Challenge, Active and Collaborative Learning, Student-Faculty Interaction, Enriching Educational Experiences, Supportive Campus Environment) or overall composite scales (see Table 15). 
Table 15

T-test analysis Examining Mean Differences Between Engagement Scales by Gender $(\mathrm{n}=280)$

\begin{tabular}{lllll}
\hline & Male & Female & & \\
& $\underline{\mathrm{n}=62}$ & $\underline{\mathrm{n}=218}$ & & \\
Engagement Variable & $\mathrm{M}(S D)$ & $\mathrm{M}(S D)$ & Possible \\
Range & $\mathrm{t}(\mathrm{df})$ \\
\hline LAC & $2.97(.53)$ & $2.97(.47)$ & $1.00-4.00$ & $.08(278)$ \\
ACL & $2.44(.52)$ & $2.49(.55)$ & $1.00-4.00$ & $.58(278)$ \\
SFI & $2.32(.57)$ & $2.28(.61)$ & $1.00-4.00$ & $.51(278)$ \\
EEE & $2.59(.54)$ & $2.51(.48)$ & $1.00-4.00$ & $1.03(278)$ \\
& & & & $.72(278)$ \\
SCE & $2.47(.66)$ & $2.39(.76)$ & $1.00-4.00$ & \\
Engagement Composite & $2.61(.42)$ & $2.58(.42)$ & $1.00-4.00$ & $.48(278)$ \\
\hline
\end{tabular}

\section{Research Question 2}

The second research question was, "Is there a statistically significant difference between the levels of college engagement for successful Black fraternity and sorority members and successful non-members?" Data indicated that mean values did not vary at a statistically significant level between Greek and Non-Greek members regarding the Level of Academic Challenge and Supportive Campus Environment scales. However, mean values did vary significantly by Greek membership on the Enriching Educational Experiences, Active and Collaborative Learning, Student-Faculty Interaction, and overall 
engagement composite scales (see Table 16). Specifically, Greek members $(n=18$; $\mathrm{M}=3.00, \mathrm{SD}=.51$ ) reported a significantly higher level of engagement within the Enriching Educational Experiences than did Non-Greek members ( $n=261 ; M=2.50$, $\mathrm{SD}=.48), \mathrm{t}(277)=4.34, \mathrm{p}<.001$. Additionally, Greek members reported a higher mean score on the Active and Collaborative Learning scale $(n=18 ; \mathrm{M}=2.81, \mathrm{SD}=.52)$ than did Non-Greek members $(n=261 ; \mathrm{M}=2.45, \mathrm{SD}=.53), \mathrm{t}(277)=2.74, \mathrm{p}<.01$. On the SFI scale Greek members scored higher $(n=18 ; \mathrm{M}=2.64, \mathrm{SD}=.58)$ than did Non-Greek members $(n=261 ; \mathrm{M}=2.26, \mathrm{SD}=.60), \mathrm{t}(277)=2.62, \mathrm{p}<.01$. For all three of these categories (Enriching Educational Experiences, Active and Collaborative Learning, and StudentFaculty Interaction) Greek members reported significantly higher levels of engagement than did Non-Greeks. Lastly, Greek members $(n=18 ; \mathrm{M}=2.84, \mathrm{SD}=.38)$ reported a higher level of engagement on the overall composite scale than did Non-Greek members $(n=261 ; \mathrm{M}=2.56, \mathrm{SD}=.42), \mathrm{t}(277)=2.72, \mathrm{p}<.01$. 
Table 16

T-test analysis Examining Mean Differences Between Engagement Scales by Greek Membership $(\mathrm{n}=279)$

\begin{tabular}{lllll}
\hline & $\begin{array}{l}\text { Greek } \\
\text { Member } \\
\mathrm{n}=18\end{array}$ & $\begin{array}{l}\text { Non-Greek } \\
\text { Member }\end{array}$ & & \\
Engagement Variable & $\mathrm{n}=261$ & & \\
\hline LAC & $2.93(.37)$ & $2.97(.49)$ & $1.00-4.00$ & $.29(277)$ \\
ACL & $2.81(.52)$ & $2.45(.53)$ & $1.00-4.00$ & $2.74(277)^{* *}$ \\
SFI & $2.64(.58)$ & $2.26(.60)$ & $1.00-4.00$ & $2.62(277)^{* *}$ \\
EEE & $3.00(.51)$ & $2.50(.48)$ & $1.00-4.00$ & $4.33(277)^{* *}$ \\
SCE & $2.57(.65)$ & $2.40(.74)$ & $1.00-4.00$ & $.99(277)$ \\
Engagement Composite & $2.84(.38)$ & $2.56(.42)$ & $1.00-4.00$ & $2.73(277)^{* *}$ \\
\hline$* * p<.01$. & & & & \\
\hline
\end{tabular}

\section{Research Question 3}

The third research question was, "Is there a statistically significant difference between the levels of college engagement for successful students whose parents completed a college degree (at least one parent with an associate's degree or higher) and successful students whose parents did not complete a college degree (both parents attended college but did not complete a degree or lower)?" Data indicated that mean values did not vary at a statistically significant level between successful Black students whose parents completed a degree and those whose parents did not complete a degree regarding any of the engagement scales (Level of Academic Challenge, Active and Collaborative 
Learning, Student-Faculty Interaction, Enriching Educational Experiences, Supportive Campus Environment) or overall composite scale.

Table 17

T-test analysis Examining Mean Differences Between Engagement Scales by Parents Education $(\mathrm{n}=262)$

\begin{tabular}{lllll}
\hline & $\begin{array}{l}\text { Parents } \\
\text { Degree } \\
\underline{n}=117\end{array}$ & $\begin{array}{l}\text { Parents } \\
\text { w/o Degree } \\
\mathrm{n}=145\end{array}$ & \\
Engagement Variable & $\mathrm{M}(S D)$ & $\mathrm{M}(S D)$ & $\begin{array}{l}\text { Possible } \\
\text { Range }\end{array}$ & $\mathrm{t}(\mathrm{df})$ \\
\hline LAC & $2.95(.49)$ & $2.99(.48)$ & $1.00-4.00$ & $.59(260)$ \\
ACL & $2.48(.58)$ & $2.48(.52)$ & $1.00-4.00$ & $.05(260)$ \\
SFI & $2.32(.62)$ & $2.27(.58)$ & $1.00-4.00$ & $.70(260)$ \\
EEE & $2.57(.50)$ & $2.51(.48)$ & $1.00-4.00$ & $.99(260)$ \\
SCE & $2.38(.74)$ & $2.48(.72)$ & $1.00-4.00$ & $1.17(260)$ \\
Engagement Composite & $2.59(.44)$ & $2.59(.39)$ & $1.00-4.00$ & $.00(260)$ \\
\hline
\end{tabular}

\section{Research Question 4}

The fourth research question was, "Is there a statistically significant difference between the levels of college engagement for successful Black students who interact with faculty often and not-often?" Data indicated that mean values varied at a statistically significant level between successful Black students who interact with faculty often and those who do not regarding the Level of Academic Challenge, Active and Collaborative Learning, Supportive Campus Environment and Enriching Educational Experience scales (see Table 18). Students who interacted with faculty often $(n=42)$ had higher levels of: 
academic challenge $(\mathrm{M}=3.33, \mathrm{SD}=.41)$ than those who did not $(n=238 ; \mathrm{M}=2.90, \mathrm{SD}=.47)$, $\mathrm{t}(278)=5.53, \mathrm{p}<.001$; active and collaborative learning $(\mathrm{M}=3.06, \mathrm{SD}=.46)$ than those who $\operatorname{did} \operatorname{not}(\mathrm{M}=2.38, \mathrm{SD}=.49), \mathrm{t}(278)=8.47, \mathrm{p}<.001$; supportive campus environment $(\mathrm{M}=2.93, \mathrm{SD}=.63)$ than those who $\operatorname{did} \operatorname{not}(\mathrm{M}=2.32, \mathrm{SD}=.72), \mathrm{t}(278)=5.26, \mathrm{p}<.001$; and enriching educational experiences $(M=3.05, S D=.34)$ than those who $\operatorname{did}$ not $(M=2.44$, $\mathrm{SD}=.46), \mathrm{t}(278)=8.12, \mathrm{p}<.001$. In this instance, it was not appropriate to report findings regarding the overall composite scale because items from the Student-Faculty Interaction scale are included in the composite scale.

Table 18

T-test analysis Examining Mean Differences Between Engagement Scales by StudentFaculty Interaction $(\mathrm{n}=280)$

\begin{tabular}{|c|c|c|c|c|}
\hline \multirow[b]{4}{*}{ Engagement Variable } & Interact & Interact & \multirow[b]{4}{*}{$\begin{array}{l}\text { Possible } \\
\text { Range }\end{array}$} & \multirow[b]{4}{*}{$\mathrm{t}(\mathrm{df})$} \\
\hline & Often & Not Often & & \\
\hline & $\underline{n}=42$ & $\mathrm{n}=238$ & & \\
\hline & $\mathrm{M}(S D)$ & $\mathrm{M}(S D)$ & & \\
\hline LAC & $3.33(.41)$ & $2.90(.47)$ & $1.00-4.00$ & $5.53(278)^{* * *}$ \\
\hline ACL & $3.06(.46)$ & $2.38(.49)$ & $1.00-4.00$ & $8.47(278)^{* * *}$ \\
\hline EEE & $3.05(.34)$ & $2.44(.46)$ & $1.00-4.00$ & $8.12(278)^{* * *}$ \\
\hline SCE & $2.94(.63)$ & $2.32(.72)$ & $1.00-4.00$ & $5.26(278)^{* * *}$ \\
\hline
\end{tabular}




\section{Research Question 5}

The fifth research question was, "Is there a statistically significant difference between the levels of college engagement for successful Black students who participate in co-curricular activities often (16 or more hours) and those who do not (15 or less hours)?" The data indicated that mean values did not vary at a statistically significant level between successful Black students who participated in co-curricular activities often and not often regarding the Active and Collaborative Learning and Supportive Campus Environment scales. However, mean values did vary significantly by co-curricular participation on the Level of Academic Challenge and Student-Faculty Interaction scales (see Table 19). Specifically, students who participate in co-curricular activities often $(n=42 ; \mathrm{M}=3.29, \mathrm{SD}=.50)$ reported a significantly higher level of academic challenge than did students who do not participate in co-curricular activities often $(n=238 ; M=2.96$, $\mathrm{SD}=.48), \mathrm{t}(278)=2.12, \mathrm{p}<.05$. Additionally, students who participate in co-curricular activities often $(n=42 ; \mathrm{M}=2.83, \mathrm{SD}=.64)$ reported a significantly higher level of interaction with faculty than did students who did not participate in co-curricular activities often $(n=238 ; \mathrm{M}=2.27, \mathrm{SD}=.59), \mathrm{t}(278)=2.98, \mathrm{p}<.01$. Here too, it was not appropriate to report findings regarding the overall composite scale because items from the Enriching Educational Experiences scale (co-curricular participation) are included in the composite scales. 
Table 19

T-test analysis Examining Mean Differences Between Engagement Scales by Cocurricular Activity Participation (n=280)

\begin{tabular}{|c|c|c|c|c|}
\hline \multirow[b]{3}{*}{ Engagement Variable } & $\begin{array}{l}\text { Participate } \\
\text { Often } \\
\mathrm{n}=42 \\
\end{array}$ & $\begin{array}{l}\text { Participate } \\
\text { Not Often } \\
\mathrm{n}=238 \\
\end{array}$ & \multirow[b]{2}{*}{ Possible } & \multirow[b]{3}{*}{$t(d f)$} \\
\hline & \multirow[b]{2}{*}{$\mathrm{M}(S D)$} & & & \\
\hline & & $\mathrm{M}(S D)$ & Range & \\
\hline LAC & $3.29(.50)$ & $2.96(.48)$ & $1.00-4.00$ & $2.12(278)^{*}$ \\
\hline ACL & $2.70(.72)$ & $2.47(.53)$ & $1.00-4.00$ & $1.31(278)$ \\
\hline SFI & $2.83(.64)$ & $2.27(.59)$ & $1.00-4.00$ & $2.98(278)^{* *}$ \\
\hline SCE & $2.80(.66)$ & $2.40(.74)$ & $1.00-4.00$ & $1.70(278)$ \\
\hline
\end{tabular}

$* p .<.05, * * p<.01$.

\section{Summary}

In summary, the respondent information gleaned from the survey results represented a gender biased student population with $78 \%$ of students being female. Although enrollment figures vary from college to college, there were student participants from each of the 11 senior CUNY colleges with at least $10 \%$ of student participants from almost half (45\%) the schools.

Most (79.9\%) of the student respondents were U.S. citizens. A large majority $(70.6 \%)$ of the student respondents were enrolled full-time. In spite of the positive impact that fraternities and sororities have on leadership development and growth, a large majority $(93.5 \%)$ of student respondents were not members of a Greek organization. A large majority $(77.3 \%)$ of student respondents live within driving distance of their 
college.

Almost one-half (45\%) of the student respondents had at least one parent that earned a college degree (Associate's or higher). A large majority (60\%) of student respondents had overall GPA's in the B (B+, B, B-) range. 


\section{CHAPTER 5}

\section{Summary, Conclusions, and Recommendations}

\section{Overview}

The purpose of this study was to understand what influences successful Black commuter students' levels of engagement in college. The study investigated what variables influence the five areas of college engagement_Level of Academic Challenge, Active and Collaborative Learning, Student Faculty Interaction, Enriching Educational Experiences and Supportive College Environment — as defined on the 2009 National Survey of Student Engagement. This chapter summarizes the results and offers conclusions from the study. Finally, implications for policy and future practice as well as recommendations for further research are presented based on significant findings.

\section{Summary of Results}

The first research question examined the differences between levels of engagement for successful Black female students and successful Black male students. This study determined that there are no significant differences between the levels of engagement for successful Black students based on gender. These results were quite interesting because 1) there were considerably more women who completed the NSSE and 2) NSSE reports that, "women are slightly more engaged than men in their educational experience..." (NSSE, 2004, p. 8). According to CUNY, women make up $58.6 \%$ of enrolled students (2011a). Approximately 78\% of NSSE respondents, however, were women compared to $22 \%$ who were men. By gender, student respondents are not representative of the population; considerably fewer men responded to the NSSE given the CUNY population. This result is surprising because the literature suggests that 
women are more engaged than men. This study contradicts the literature and says that students who completed the survey had similarly high levels of engagement.

The second research question examined the differences between levels of engagement for successful Black fraternity and sorority members and successful Black non-members (see Table 16). For the second research question, the main findings are:

- Members of fraternities and sororities are significantly more engaged in the areas of Active and Collaborative Learning, Student-Faculty Interaction, and Enriching Educational Experiences than students who are not members of a fraternity or sorority.

- Although there is not a statistically significant difference between the mean scores for fraternity and sorority members and non-members in the areas of Level of Academic Challenge and Supportive Campus Environment, fraternity and sorority members are more engaged when all areas of engagement are combined, which is consistent with NSSE findings.

The third research question examined the differences between levels of engagement for successful Black students whose parents completed a college degree and successful Black students whose parents did not complete a degree. NSSE reports that, "Students whose parents hold college degrees are slightly more engaged than firstgeneration college students in a variety of college activities" (NSSE, 2004, p. 9). This study, however, determined that there are no significant differences between the levels of engagement for successful Black students based on their parents' education. 
The fourth research question examined the differences between levels of engagement for successful Black students who interact with faculty often and those who do not (see Table 18). For the fourth research question, the main finding is:

- Students who interact with faculty often are significantly more engaged in the areas of Active and Collaborative Learning, Enriching Educational Experiences, and Supportive Campus Environments than those who do not interact with faculty often.

This finding supports research (Astin, 1984, 1999; Kuh, 2003; Kuh et al., 1989), which contends that students' interaction with faculty often enhance their engagement in other educationally effective areas.

The fifth research question examined the differences between levels of engagement for successful Black students who participate in co-curricular activities often and those who do not (see Table 19). For the fifth research question, the main finding is:

- Students who participate in co-curricular activities often are significantly more likely to have higher levels of engagement in the areas of Level of Academic Challenge and Student-Faculty Interaction than students who do not participate in co-curricular activities.

\section{Conclusions}

\section{Areas of Engagement}

Level of academic challenge. A majority of Black commuter students at CUNY reported that their coursework emphasized analyzing the basic elements of an idea, experience, or theory (86.5\%) either quite a bit or very much; synthesizing ideas, information or experiences (75.4\%) either quite a bit or very much; making judgments 
about the value of information, arguments, or methods (74\%) either quite a bit or very much; and applying theories to practical problems or in new situations (83.2\%) either quite a bit or very much. Although only approximately half (47.3\%) of the students reported spending at least 11 hours preparing for class, a majority (82.5\%) of students reported that CUNY emphasizes spending significant amounts of time studying and on academic work. These findings suggest that CUNY is committed to developing intellectual competence (Chickering, 1969) by creating an academic environment that is conducive to mastering Bloom's (1956) higher order thinking skills (analysis, synthesis, and evaluation). These findings also suggest that students who spend fewer than 11 hours preparing for class may have other non-academic responsibilities (family, work, etc.) and priorities (Chickering, 1974; Jacoby, 1989) that prevent them from devoting significant amounts of time to prepare for class.

Student-faculty interaction had a significant effect on Black students' Level of Academic Challenge. A majority (64.3\%) of respondents reported that they either often or very often worked harder to meet the instructor's standards or expectations. These findings suggest that students who interact with faculty often understand the importance of academic effort and value the high expectations set for them. Frequent participation in co-curricular activities, including Greek membership, also had a significant effect on Black commuter students' Level of Academic Challenge. These findings are consistent with research that asserts that students benefit from their college experience when they are both academically and socially integrated into the university (Tinto, 1987).

A student who is "...highly involved...devotes considerable energy to studying..." (Astin, 1984, p. 297). Similarly, a student who finds that the “...academic 
life of the institution is not challenging enough" becomes disengaged and will depart from the institution (Tinto, 1987, p. 55).

Active and collaborative learning. A majority (74.4\%) of students reported that they either often or very often ask questions or contribute to discussions in class. These findings are inconsistent with Pascarella and Terenzini's (2005) study that found that lecturing still remains the most popular used instructional technique among faculty. These findings suggest that interactive instructional techniques dominate CUNY classes.

Members of Greek organizations and students who interact with faculty often reported higher levels of Active and Collaborative Learning. These findings are consistent with research that discusses the impact of active and collaborative learning in the classroom because “...the classroom functions as a gateway for student involvement in the academic and social communities of a college" (Braxton et al., 2000, p. 570). These findings are also consistent with research that discusses the impact of Greek membership (Astin, 1969; Baker, 2008; Harper, 2008; Kimbrough \& Hutcheson, 1998; Kimbrough, 1995; Pascarella et al., 1996) and student-faculty interaction on involvement (Astin 1984, 1985, 1977, 1993, 1999; Kuh \& Hu, 2001; Kuh et al., 2010; Lundberg \& Schreiner, 2004; Pascarella and Terenzini 1991, 2005; Terenzini et al., 1993; Tinto, 1993; Umbach \& Wawrzynski, 2005). Membership in Greek organizations provides opportunities for leadership development and growth. It also provides opportunities for students to interact and work with other members. Similar opportunities are provided when students are exposed to active and collaborative learning techniques in the classroom. 
Student-faculty interaction. Numerous studies and reports confirm the positive effects associated with student-faculty interaction (Astin 1984, 1985, 1993, 1999; Kuh \& Hu, 2001; Kuh et al., 2010; Lundberg \& Schreiner, 2004; Pascarella \& Terenzini, 1991, 2005; Terenzini et al., 1993; Tinto, 1993; Umbach \& Wawrzynski, 2005). Astin (1984) asserts that a student who is "...highly involved...interacts frequently with faculty members..." (p. 297).

Kuh (2003) argues that student interaction with faculty “....matters most to learning when it encourages students to devote greater effort to other educationally purposeful activities during college” (p. 29). Swail et al. (2003) posit that “...faculty members are often role models...[and]...provide guidance, direction, and, most important[ly] a good example for [Black] students to learn from" (p. 65). Clearly, faculty members are critical to improving undergraduate education outcomes for Black commuter students.

This study revealed that Student-Faculty Interaction had the greatest impact on all levels of student engagement. These findings are consistent with previous research studies (Astin, 1993, 1999; Kuh, 2003), which found that interaction with faculty encourages students to engage in other educationally purposeful activities during college. Students in this study who had high levels of interaction with faculty also reported higher levels of engagement with the Level of Academic Challenge, Active and Collaborative Learning, Enriching Educational Experiences, and Supportive Campus Environment. It is interesting to note that of all the findings, Student-Faculty Interaction is the only area of engagement that had an impact upon how students perceive the campus environment. Students who interact with faculty often reported higher levels of engagement on the 
Supportive Campus Environment scale, which required participants to rate how supportive the campus is of their academic, non-academic, and social needs as well as rate the quality of relationships with people at their institution.

Enriching educational experiences. There are many benefits to attending college that are linked to co-curricular activities and experiences (Astin, 1977, 1993, 1999; Chickering \& Gamson, 1987; Kuh, 1993; Kuh et al. 2008; Pace, 1979; Pascarella $\&$ Terenzini, 1991, 2005). These experiences include learning about diverse people and cultures, using technology for assignments, and participating in internships, community service, study abroad, and co-curricular activities (NSSE, 2011). A majority (72.7\%) of students reported that regarding hands-on experience in their field of study (practicum, internship, field experience, co-op experience, or clinical assignment), they either plan to do it before graduation or have done it. These findings suggest that CUNY is committed to preparing students for success beyond the classroom. A majority (73.9\%) of students reported that regarding community service or volunteer work, they either plan to do it before graduation or have done it. These findings support Sutton and Kimbrough's (2001) claim that Black students are committed “...to serve disenfranchised members of the community...[and]...share their skills and talents with the African American community" (p. 32).

Greek membership had a significant effect upon Enriching Educational Experiences. These findings are consistent with research studies, which found that Greek membership enhances student involvement in college (Astin, 1969; Baker, 2008; Harper, 2008; Kimbrough \& Hutcheson, 1998; Kimbrough, 1995; Pascarella et al., 1996). Student-faculty interaction also had a significant effect upon Enriching Educational 
Experiences. These findings are consistent with research that asserts that student experiences with faculty often influence students' level of engagement in other areas of effective educational activities (Astin 1984, 1985, 1977, 1993, 1999; Kuh \& Hu, 2001; Kuh et al., 2010; Lundberg \& Schreiner, 2004; Pascarella and Terenzini 1991, 2005; Terenzini et al., 1993; Tinto, 1993; Umbach \& Wawrzynski, 2005).

Supportive campus environment. Kuh and $\mathrm{Hu}$ (2001) argue that colleges and universities must “...develop and sustain a welcoming, supportive, [and] affirmative environment..." (p. 328) for all students. In fact, much of the literature about college student involvement and retention mentions the importance of a supportive campus environment (Astin, 1968, 1975, 1977, 1984, 1985, 1993, 1999; Berger \& Milem, 1999; Chickering, 1979; Fleming, 1984; Freeman, 1998; Jacoby, 1989; Kuh, 1993, Kuh et al., 2006; Pace, 1979; Pascarella \& Terenzini, 1991, 2005; Swail et al., 2003; Tinto, 1987). Tinto (1987) found that, “...black students in particular...find it especially difficult to find and become a member of a supportive community within the college” (p. 71).

According to NSSE (2011), "Students perform better and are more satisfied at colleges that are committed to their success..." (p. 2). This dissertation study found that students who interact with faculty often reported higher mean scores on the Supportive Campus Environment scale, which rates the campus environment (see Table 18). The findings of this study suggest that students who interact with faculty often perceive the campus to be more supportive than students who do not interact with faculty often. These findings are consistent with Astin's (1999) study, which found that students “...who interact frequently with faculty members are more likely than other students to express satisfaction with all aspects of their institutional experience, including...the 
administration of the institution" (p.525). It was surprising, however, that a large majority (73.2\%) of students did not find the institution to be very supportive of their non-academic responsibilities (work, family, etc.) especially because research (Chickering, 1974; Jacoby, 1989) asserts that commuters have to maintain a balance between school and other responsibilities. These findings suggest that students may experience higher levels of engagement regarding a Supportive Campus Environment if more services were provided to help them cope with non-academic responsibilities.

\section{Gender}

This study found that there are no significant differences in levels of engagement between successful Black male and female students. Although these findings are consistent with Harper et al.'s (2004) study on gender and HBCU student engagement, they are inconsistent with the majority of research (Bae et al., 2000; Buchmann, 2006; Diprete \& Buchmann, 2006; Jacobs, 2002; NCES, 2005), which asserts that females have an advantage over males in higher. These inconsistencies may, according to Buchmann and DiPrete (2006), be attributed to "the female advantage in college performance [being] weaker for [Black] students...” (p. 534). Undergraduate enrollment trends of Black males and Black females are disproportionate-Black females accounted for $64 \%$ of Black undergraduate enrollment in institutions across the United States (NCES, 2010). In this dissertation study, it appears that, once enrolled and presented with opportunities to be involved, male and female students exhibit similar levels of engagement.

In this dissertation study, the sample disproportionately favored females over males. This phenomenon suggests that the Black male students who participated were engaged and more inclined to complete the NSSE survey, and the Black male students 
who didn't participate are less engaged and, therefore, less inclined to respond to the survey.

\section{Fraternity/Sorority Membership}

Baker (2008) posits that although "Fraternities and sororities are among the most established and prominent student organizations on college campuses...they are most often criticized for maintaining a culture that promotes gender and racial inequality" ( $\mathrm{p}$. 277). Many institutions of higher education fail to recognize the benefits of Greek organizations and disassociate themselves from these organizations or ban them all together (Mickens, 2007), in spite of the research that touts their value. Kimbrough and Hutcheson (1998), Kimbrough (1995), and Pascarella et al., (1996) and Pike (2000) assert that membership in fraternities and sororities positively affect leadership and cognitive development. In this study, members of Greek organizations reported significantly higher levels of engagement on the Educationally Enriching Experiences scale. Astin (1969) found that participation in co-curricular activities, “...especially membership in...fraternities and sororities, is also related to [retention]" (p. 108). This suggests that Greek members will persist to graduation.

Kimbrough and Hutcheson (1998) contend that fraternity and sorority “...membership provides an important means by which to enhance student involvement and leadership development for Blacks in college and beyond" (p. 96). Harper's (2008) study on Black fraternity and sorority members found that Greek "....affiliation [leads] to productive engagement inside the classroom" (p. 112), which is consistent with the findings of this dissertation study regarding the Active and Collaborative Learning scale. The Kimbrough and Hutcheson (1998) and Harper (2008) studies highlight the social and 
academic integration (Tinto, 1987) benefits of Greek membership. Students in this dissertation research who are members of Greek organizations also reported higher levels of interaction with faculty. This finding suggests that because members of Greek organizations benefit from networking (Baker, 2008), they utilize their interaction with faculty as opportunities to network.

\section{Parents' Education}

NSSE reports that, "Students whose parents hold college degrees are slightly more engaged than first-generation college students in a variety of college activities" (NSSE, 2004, p. 9) and Astin $(1975,1982)$ found that persistence is positively associated with parental education. This dissertation study found that there are no statistically significant differences between the levels of engagement for successful Black students at CUNY based on their parents' education. Students whose parents had a degree $(n=117)$ and students whose parents did not have a degree $(n=145)$ reported similar levels of engagement.

It is important to note that CUNY was founded upon the belief of providing a quality education for the children of immigrants (CUNY, 2010). Not surprising, many CUNY students are children of people who immigrated to this country in search of the American Dream. Black immigrants, in particular, came with “... a belief that education is the key to success and a drive for their children to do well”' (Foner, 2001, p. 219). Because of the value placed on education, “... and high expectations for their children's success", these students are encouraged to do well in college (Foner, 2001, p. 214). Foner asserts "...that immigrant parents, as a whole, have higher educational aspirations for their children and more positive attitudes toward schooling than native-born parents" 
(p. 215). This may explain participants' similar levels of engagement based on parents' education.

\section{Co-Curricular Activities}

Astin (1984) asserts that students who are “...highly involved...spends a lot of time on campus [and] participates actively in...[co-curricular activities]" (p. 297). Foubert and Grainger (2006) found that students who were involved in clubs and organizations demonstrated higher levels of development. Sutton and Kimbrough (2001) found that involvement in co-curricular activities are critical to Black students' college experience and encourage “...Black student participation within organizations that develop and influence institutional policy such as student government" (p. 38). Students in this study who participated in co-curricular activities often reported higher levels of engagement with the Level of Academic Challenge. This finding supports research that discusses the importance of being both academically and socially integrated with the college experience (Tinto, 1987). Students in this study who participated in co-curricular activities also reported higher levels of interaction with faculty. This finding, too, is consistent with research studies (Astin, 1993, 1999; Kuh, 2003), which found that students who interact with faculty tend also to be involved in educationally purposeful activities such as co-curricular activities.

\section{Implications for Policy and Practice}

Evans, Forney, and Guido-DiBrito (1998) assert that, "the growth and development of students is a central goal of higher education...” (p. 2). In order to effectively achieve this goal and contribute to the growth and development of the diverse student populations we serve, “...higher education policymakers and practitioners...must 
better understand how to foster success among students of color" (Museus \& Quaye, 2009 , p. 68). It is the responsibility of college and university leaders to “...build [institutions] where [students] are continually expanding their capabilities to shape their future" (Senge, 2000, p. 289). The following recommendations will help CUNY colleges and other commuter universities move from access to success (Swail et al., 2003).

\section{Promoting Benefits and Visibility of Fraternities and Sororities}

The findings of this study suggest that successful Black students benefit from membership in Greek organizations. Sadly, only a small percentage (6.5\%) of students reported being members of a fraternity or sorority. Because Greek membership influences CUNY's successful Black students' level of engagement, the first recommendation for practice is to promote the benefits and encourage visibility of fraternities and sororities on campus. CUNY can help enhance the success of Black students by providing greater institutional support of fraternities and sororities, especially historically Black Greek-Lettered Organizations (BGLO's). Black Greek-Lettered Organizations were created in the early 1900's to provide a supportive educational environment for Black undergraduates. These organizations focus on scholarship and encourage academic excellence among its members. Most of the Black Greek-Lettered Organizations (BGLO's) were founded upon a commitment to serve and uplift the community and, presently, still provide countless hours of voluntary service to their respective communities.

Currently, there is no CUNY-wide policy regarding Greek life. CUNY's nondiscrimination policy (2011d), however, prohibits fraternities and sororities from receiving any funding. Harper and Quaye (2007) argue that "educators and 
administrators who are interested in increasing engagement...among African American... undergraduates must provide financial...support to predominantly Black and minority student organizations" (p. 142). Title IX of the Education Amendments of 1972 clearly states that discrimination based on gender does not apply to membership practices of social fraternities or sororities. CUNY should first carefully examine the benefits associated with Greek- Lettered Organizations, and then create a University wide policy that supports Greek life on all campuses. CUNY should also amend its nondiscrimination policy to permit allocation of funds to support involvement and leadership development opportunities that fraternities and sororities offer its members. This allocation of resources to Greek-Lettered Organizations will also help fund initiatives that benefit both members and non-members.

For example, Zeta Phi Beta Sorority, Incorporated, a sorority recognized on a number of CUNY campuses, hosts many programs including, responsible sexual behaviors, domestic violence, study skills, money management, and career planning for undergraduate students through its national initiative: Z-HOPE (Zetas Helping Other People Excel). Z-HOPE "is an interactive, outreach service initiative designed to enhance, cultivate and empower participants to develop healthy lifestyle choices across the lifespan" (Zeta Phi Beta, 2011). These programs are sponsored through financial support from members' dues. Programs such as these should be encouraged on CUNY campuses and supported by administration. With tuition and living expenses on the rise, fraternity and sorority members may no longer be able to host programs that help students integrate academically and socially (Tinto, 1993) at the institution. Commuter 
colleges and universities can use Greek organizations as a vehicle to improve student engagement and retention.

Administrators and student affairs practitioners should provide additional opportunities for fraternity and sorority visibility on campus. Fraternity and sorority members should play an important role in the planning of freshmen orientation and should have an opportunity to speak about the benefits of Greek membership at the orientation. Institutions should have a designated Greek day each week where all members (student, faculty, and staff) of Greek Lettered Organizations are encouraged to wear paraphernalia on campus. "Benefits of Being Greek" brochures should be created and included in admissions packets. These brochures should contain quotes from members of Greek organizations about various membership benefits. Greek advisors should work closely with undergraduate chapter members as well as the chapters' graduate advisors (where applicable) to determine how institutions can help fraternities and sororities increase membership and better serve the campus community.

\section{Enhancing Student-Faculty Interaction}

The role of faculty cannot be overstated. Frequent student-faculty interactions allow faculty to " ...become role models, mentors, and guides for continuous life-long learning" (Kezar \& Kinzie, 2006, p. 151). The findings of this study suggest that successful Black commuter students benefit from their interaction with faculty. Chickering found that "extensive and varied interaction among faculty and students facilitate development [when]...students [can] perceive faculty as real people who are accessible and interested in them beyond the classroom" (as cited in Evans et al., 1998, p. 41). 
Because commuter students interact with faculty less than resident students (Chickering, 1974), the second recommendation for practice is to enhance student-faculty interaction both inside and outside the classroom. Umbach and Wawrzynski (2005) posit that faculty members “ ... play the single-most important role in student learning...[and]...play a critical component of the collegiate experience...” (p. 176). Lundberg and Schreiner (2004) assert that "relationships with faculty [are] strong predictors of learning...for students of color" (p. 549). In a 2010 report on studentfaculty interaction at CUNY, Crook and Littman confirmed that "interaction with...faculty is central to student engagement [because] student engagement is correlated with retention and graduation" (p. 2). Clearly, in order to enhance their overall success, Black students must experience "frequent interactions with faculty members, especially those that encourage students to work harder" (Lundberg \& Schreiner, 2004, p. 559). Faculty could facilitate this interaction by applying Chickering \& Gamson's (1987) Seven Principles of Good Practice in Undergraduate Education in their classrooms. These principles are:

1. Encourages contact between students and faculty.

2. Develops reciprocity and cooperation among students.

3. Encourages active learning.

4. Gives prompt feedback.

5. Emphasizes time on task.

6. Communicates high expectations.

7. Respects diverse talents and ways of learning. 
Faculty could also facilitate this interaction by adopting the qualities of a successful mentor as outlined by Cramer and Prentice-Dunn (2007). These qualities require faculty members to be:

1. Available

2. Knowledgeable

3. Educated in Diversity Issues

4. Empathetic

5. Personable

6. Encouraging/Supportive

7. Passionate

Implementation of these seven principles and seven qualities could enhance studentfaculty relationships, interaction and, ultimately, learning and development.

Administrators should provide professional development for faculty to learn new and innovative ways of interacting with students and clearly communicating expectations. For example, Engagement Consultants could be hired to facilitate workshops to teach faculty how to incorporate engagement techniques into the classroom. Additionally, a "Technique of the Month" could be created to publicly highlight techniques used by faculty to ensure high levels of engagement. Professors and students can both submit creative techniques that enhanced student-faculty interaction. Professors can share these techniques at monthly faculty meetings and upload them to an "Interaction Techniques" folder accessible to faculty via blackboard. Professional development workshops could also be used to teach faculty innovative ways to maximize blackboard use to engage students. 
In the classroom, faculty should find creative ways to provoke thought. Ewell (1997) suggests presenting real-life problems in order to maximize students' learning. He argues that students will invest energy in learning when they are prompted to think about problems they have to solve. It is important for faculty to know the strengths and capabilities of each of their students in order to avoid them shutting down. This is especially true for Black students who often enter college underprepared (Astin, 1975; Astin et al., 1982; Chickering, 1969; Fleming, 1984; Freeman, 1998; Swail et al., 2003; Tinto, 1987). Fleming's (1984) study found that Black students at Predominantly White Institutions did not meet any of the academic goals described in the school's catalogue, which suggests that the academic achievement of Black students isn't supported at some universities. Institutions of higher education must ensure that even if students enter underprepared, they still “ $\ldots$..have the opportunity to acquire the skills needed for academic success" (Tinto, 1987, p. 138). The development of these skills will enhance the quality of student effort, which greatly affects academic outcomes (Pace, 1979).

Faculty should also identify opportunities to facilitate learning outside the classroom. Out-of-class conversations "... about how the students can use what they are learning in their lives outside the classroom and beyond the campus" (Kuh \& Hu, 2001, p. 328) would be beneficial.

More than half (55.1\%) of the respondents in this study reported that they never worked with faculty members on activities other than coursework (see Table 4). Undergraduate student and faculty collaboration on research projects should undoubtedly be encouraged. Administrators should consider sponsoring students who work with faculty on research projects to attend professional meetings or other events in their 
respective fields with faculty. Creating a more engaging campus environment that promotes a culture of student-centeredness and encourages student-faculty interaction is a vital.

Consideration should be given to establishing clear, common areas for students and faculty to interact because space is necessary to support the engagement of commuter students. When University leaders are creating budgets, they must consider the cost to create not only classroom and office space, but also student "engagement" space. CUNY's leaders and Board of Trustees should work in partnership to create policies that focus on enhancing students' college experience. Proposals should be sent to external funders and State and Legislative stakeholders to build new, or remodel existing, engagement spaces to accommodate the needs of commuter students.

Many CUNY student clubs and organizations function without faculty advisors. Appointing faculty to advise these clubs could be a strategy to enhance student-faculty interaction. Many of the CUNY colleges have club hours (prescribed days and times) for student clubs and organizations to meet and/or host programs. During these designated times, classes are usually not scheduled. Utilizing this time to facilitate greater interaction, where students and faculty have an opportunity to connect and discuss research projects or current events would enhance student-faculty interaction and increase students' levels of engagement. Moreover, this would allow opportunities for mentorship, which would give faculty “...a unique opportunity to serve as personal connections, informational resources, and professional role models for young adults" (Cramer \& Prentice-Dunn, 2007, p. 756). 
This interaction is not limited to the campus. Off-campus activities should be encouraged to enhance student-faculty interaction. Considering that only (12.3\%) of students reported participating in service-learning activities (see Table 3), academic affairs and student affairs professionals can work together to create and promote servicelearning opportunities for students. Service learning is defined as:

a credit-bearing educational experience in which students participate in an organized service activity that meets identified community needs and reflect on the service activity in such a way as to gain further understanding of course content, a broader appreciation of the discipline, and an enhanced sense of civic responsibility (Bringle \& Hatcher, 1996, p. 222)

CUNY students and undergraduates at similar urban institutions could benefit from enrolling in service-learning courses that integrate “...their multiple life roles on campus and in the community" (Bringle \& Hatcher, 1996, p. 231).

Administrators should provide incentives for faculty support of student events. Instituting a "Supportive Faculty Member of the Month" where students nominate the faculty member who supports the most student events is a strategy that could be implemented. The selected faculty member can be recognized on the university website, in the student and campus newspaper, publicly at the next student event he/she supports and possibly receive free parking for a month on campus and a $\$ 10$ gift card to a local coffee shop. This could certainly encourage faculty support of student events as well as student-faculty interaction. Increased interaction can help shape how students and faculty relate to each other and create a mutually beneficial campus culture that is conducive to teaching and learning both inside and outside the classroom. 
Finally, to truly enhance student-faculty interaction, faculty incentives must be considered. Because publishing is one of the primary requirements for tenure and promotion, and the demands are so time consuming, it is impossible for faculty members to devote considerable amounts of time to interacting with students. CUNY should change its policy to include other incentives for promotion and tenure. For example, faculty should be considered for promotion and tenure not only because of their scholarship, but also for their service and contributions to the creation of a more engaging campus environment for students. If CUNY is committed to the success of all students, then faculty should be given options for tenure that include a focus on documented contributions to student success.

\section{Enhance Participation in Co-Curricular Activities}

In this dissertation study, a majority $(66.4 \%)$ of students reported that they do not participate in co-curricular activities (see Table 5). These numbers are consistent with the number of students $(66.6 \%)$ that reported that providing support to thrive socially is not a priority for CUNY (see Table 6). This is troubling because previous research studies found that participation in co-curricular activities positively impact students' learning and development (Pace, 1969; Kuh, 1993; Kuh et al., 1989), especially when participation begins upon entry (Arnold, 1993; Terenzini et al., 1993). These findings suggest that CUNY needs to identify ways to increase undergraduate participation in cocurricular activities in order to enhance Black students' levels of engagement and social integration. A collaborative effort between student affairs personnel, academic advisors, and faculty must occur to improve participation trends. 
Because commuter students often view the institution as a place to visit (Jacoby, 1989, 2000), administrators should conduct a needs assessment to consider student perspectives and determine co-curricular activities that are most meaningful to them. Once administrators and related personnel identify student needs, a strategy must be put in place to create those activities and get all students to participate. One way to enhance participation is by utilizing affinity groups including clubs/organizations, athletics, childcare, veterans, etc. For example, parenting workshops or events that are child-friendly could be created to attract students who utilize child-care services. "Coping with Stress" and similar programs could be created to get veteran students involved. Creating an environment that welcomes students from different populations who have different needs could enhance student participation. It is the responsibility of University leaders to meet and engage students where they are.

Another way to enhance participation is by marketing. First, commuter colleges and universities can improve marketing by utilizing on-campus media that are readily available. Advertise upcoming events that will appeal to students and visitors in a prominent area of the university's website. Students often say that they did not attend an event because they did not know about it even if it was posted on the website. The website should attract interest to what is being advertised. Students frequent social networks (facebook, twitter, etc.). Administrators should encourage each department to create an account on at least one of the social networking sites. This will allow for greater marketing of events in places that are recognized and used frequently by students. Student media-campus radio, TV, newspapers, blogs, etc.—should be used to promote events. Advertising in campus newspapers, the cafeteria, and on bulletin boards are still 
great strategies to increase participation. Campus "street teams" should be activated to "hit the campus" and promote events. If planned well in advance, a calendar of events can be included in admissions materials. Second, colleges and universities should consider transforming into technologically saavy institutions. We live in a technology driven society, and students are active participants. Iphone, android, and other smart phone applications should be created to disseminate information to students. Event reminders and university updates can be sent via those applications. Finally, encourage faculty to post on blackboard and announce in their classes and/or departments as well as attend events.

\section{Enhancing Student Affairs and Academic Affairs Collaboration}

Approximately one-third (33.3\%) of students in this dissertation study perceived CUNY as committed to providing support to help them thrive socially compared to approximately two-thirds $(68.7 \%)$ of students who believe the University is committed to their academic success (see Table 6). These results are alarming because research (Tinto, 1987) asserts that students must be both academically and socially integrated into the fabric of the University. Clearly, CUNY's social agenda needs improvement in order to increase student engagement and learning. One way to improve this deficiency is by encouraging a stronger partnership between Student Affairs and Academic Affairs personnel. With over 200,000 undergraduate students enrolled at CUNY (CUNY, 2011c), it would impossible for one division to institute change on its own. Although many student affairs staff are responsible for "...providing the programs and services to meet [students'] academic and social needs outside the classroom...[DEEP institutions']...student affairs staff...do this...in full partnership with academic affairs..." 
(Kuh et al., 2010, p.164). CUNY should employ the Academic/Student Affairs

Collaboration Model used at DEEP institutions to enhance the levels of student engagement, learning, and success on its campuses.

\section{Develop Scholarly Research and Writing Skills}

In this study, a majority $(88.2 \%)$ of students indicated that they wrote zero to four papers or reports that were twenty or more pages in length (see Table 2). CUNY should encourage more scholarly, research-based writing for undergraduate students. The development of scholarly writing should be encouraged because graduate school admissions offices, as well as certain jobs, require writing samples for acceptance. Challenging students to write more will prepare them for the requirements of graduate level work. This also suggests that the University sets high expectations for its students and foster their commitment to lifelong learning and to academic success beyond the classroom. An opportunity to work with faculty members on research projects is another strategy for developing writing skills.

\section{Recommendations for Future Research}

\section{Conducting Interviews with Black Students who are Less Engaged than their Peers}

According to Patton (2002), qualitative research facilitates the "study of issues in depth and detail... and typically produce[s] a wealth of detailed information..." (p. 14). The first recommendation for further research is to conduct interviews with Black students who are less engaged than their peers in order to, “...open up a world to the reader through rich, detailed, and concrete descriptions of people and places" and further investigate what influences engagement and success (Patton, 2002, p. 438). Interviewing students who are not members of Greek organizations, do not interact with faculty often, 
and who do not participate in co-curricular activities often will allow the University to identify factors influencing lack of engagement and identify ways to enhance the levels of engagement for Black commuter students.

\section{Investigating Significant Differences between New York City (NYC) Public School}

\section{Students and Non-New York City Public School Students}

A large majority (70\%) of first-time CUNY freshmen graduated from a NYC

Public high school (CUNY, 2010). The second recommendation is to investigate whether there are significant differences in levels of engagement based on students' public school experience. Research (Astin, 1975; Astin et al., 1982, Freeman, 1998; Tinto, 1987, 1993) asserts that prior educational experiences influence a student's college experience. A study such as this would provide implications for the NYC Department of Education that will help institute policies and programs to help its students succeed not only in public school, but also in college.

\section{Investigating Significant Differences between CUNY Freshman Students who Participated In Collaborative Programs during High School and CUNY Freshman who Did Not Participate in Collaborative Programs}

The City University of New York has several programs that collaborate with the NYC Department of Education. CUNY's collaborative programs (College Now, Middle Grades Initiative/Gear Up, Creative Arts Team, Early College Initiative, CUNY Prep, and At Home in College) boast their commitment to the education of NYC public school students begin before they start freshman year (CUNY, 2010). Each of these programs focuses on strengthening academic skill and college readiness. A couple of these programs begin as early as middle school and last throughout high school graduation. In 
fact, Astin et al. (1982) found that minority students reported more satisfaction when they took college preparatory classes in high school. The third recommendation is to investigate whether there are any significant differences between the levels of engagement for freshmen who participated in CUNY's collaborative programs and freshmen who did not participate in CUNY's collaborative programs. Because engagement is a great predictor of success when combined with academic preparation, CUNY would determine what, if any, programmatic changes must be made to enhance the effectiveness of its collaborative programs.

\section{Investigating Significant Differences by Race/Ethnicity}

The fourth recommendation is to investigate whether there are any significant differences in levels of engagement based on race/ethnicity. This dissertation study focused specifically on Black students and did not include other races. A study by Leinbach and Bailey (2006) about Hispanic students at CUNY found that although enrollment rates increased, Hispanic students were not earning degrees at the same rate. These findings are consistent with previous research that found that Black students were enrolling, but not persisting to graduation (NCES, 2010). Given the similarities between Black and Hispanic students, it would be interesting to see if there are any significant differences between the levels of engagement of these two groups at CUNY.

\section{Investigating Significant Differences by Colleges}

The fifth recommendation is to investigate whether there are any significant

differences in levels of engagement based on various colleges in the CUNY system. This study investigated engagement for successful Black commuter students at all the senior colleges at the City University of New York. The researcher did not conduct a campus 
specific dissertation study due to the low response rate of CUNY students. The overrepresentation of women in this dissertation study was interesting. Further research about levels of engagement at specific colleges would allow campuses to: 1) identify what influences the success of Black students at their institution in order to share university-wide benchmarks of success; and 2) create strategies to encourage more Black male participation.

\section{Investigate the Impact of the Black Male Initiative (BMI) on Black Male}

\section{Engagement}

Contrary to research about engagement and gender (NCES, 2005; NSSE, 2004), this dissertation study found that Black males and females at CUNY are engaged at similar levels. The Black male participants' involvement in CUNY's BMI was unknown, but could have provided insight regarding the inconsistencies of the research. One of the purposes of CUNY's BMI is to help the University's Black males overcome inequalities and succeed (CUNY, 2005). Further research to determine whether BMI participation influences Black males' level of engagement in college could provide results to document the success of this program.

\section{Investigating Significant Differences by Academic Major}

Astin (1977) found that students whose academic majors correlated with their career goals were more likely to be successful than students with unidentifiable goals. This research study revealed that a majority $(64.7 \%)$ of students either never or sometimes talked about career plans with a faculty member or advisor (see Table 4). This study did not focus on the declared major of the participants. Future research to 
investigate significant differences by academic major could provide best practices for career planning and advising within the University.

According to Huba and Freed (2000), assessment is, "The process of gathering and discovering information from multiple and diverse sources in order to develop a deep understanding of what students know, understand and can do with their knowledge as a result of their educational experiences; the process culminates when assessment results are used to improve subsequent learning" (p. 8). The researcher cautions administrators and faculty to gather information from multiple sources and not solely rely on the findings of NSSE. 


\section{References}

American Council of Learned Societies (2007). Student learning and faculty research: Connecting teaching and scholarship. Retrieved on January 16, 2011 from http://www.teaglefoundation.org/learning/pdf/2006_acls_whitepaper.pdf

Arnold, K. D. (1993). The fulfillment of promise: Minority valedictorians and salutatorians. In F. K. Stage (Ed.), College students: The evolving nature of research (pp. 84-99). Needham Heights, MA: Simon \& Schuster Custom Publishing.

Astin, A. W. (1968). The college environment. Washington, DC: American Council on Education.

Astin, A. W. (1975). Preventing students from dropping out. San Francisco: Jossey-Bass.

Astin, A. W. (1977). Four critical years. San Francisco: Jossey-Bass.

Astin, A. W. (1984). Student involvement: A developmental theory for higher education. Journal of College Student Personnel, 25, 297-308.

Astin, A. W. (1985). Achieving academic excellence. San Francisco: Jossey-Bass.

Astin, A. W. (1993). What matters in college?: Four critical years revisited. San Francisco: Jossey-Bass.

Astin, A. W. (1999). Student involvement: A developmental theory for higher education. Journal of College Student Development, 40(5), 518-29.

Astin, A. W., Astin, H. S., Green, K. C, Kent, L., McNamara, P., \& Williams, M. (1982). Minorities in American higher education. San Francisco: Jossey-Bass.

Association of American Colleges and Universities. (2007). College learning for the new global century. Retrieved on April 20, 2011 from http://www.aacu.org/advocacy/leap/documents/GlobalCentury_final.pdf

Bae, Y., Choy, S., Geddes, C., Sable, J., \& Snyder, T. (2000). Trends in educational equity of girls and women. Washington, DC: National Center for Education Statistics. 
Baker, C. (2008). Under-represented college students and extracurricular involvement: The effects of various student organizations on academic performance. Social Psychology of Education, 11(3), 273-298.

Barr, R. B. \& Tagg, J. (1995). From teaching to learning: A new paradigm for undergraduate education. Retrieved June 1, 2011, from http://ilte.ius.edu/pdf/barrtagg.pdf

Bean, J. \& Metzner, B. (1985). A conceptual model of nontraditional undergraduate student attrition. Review of Educational Research, 55(4), 485-540.

Berger, J. B. \& Milem, J. F. (1999). The role of student involvement and perceptions of integration in a causal model of student persistence. Research in Higher Education, 40(6), 641-64.

Bonwell, C. C. \& Eison, J. A. (1991) Active learning: creating excitement in the classroom. Retrieved on June 1, 2011 from http://www.oid.ucla.edu.www.libproxy.wvu.edu/about/units/tatp/old/lounge/pedago gy/downloads/active-learning-eric.pdf

Braxton, J.M., Hirschy, A.S., \& McClendon, S.A. (2004). Understanding and reducing college student departure. ASHE-ERIC Higher Education Report Volume 30, Number 3. San Francisco: Jossey-Bass.

Braxton, J.M, Milem, J.F., \& Sullivan, A.S. (2000). The influence of active learning on the college student departure process: Toward a revision of Tinto's theory. Journal of Higher Education, 71(5), 569-590.

Bridges, B. K., Cambridge, B., Kuh, G., \& Leegwater, L. (2005). Student engagement at minority serving institutions: Emerging lessons from the BEAMS project. New Directions for Institutional Research, 125, 25-43.

Bringle, R. G., \& Hatcher,J. A. (1996). Implementing service learning in higher education. Journal of Higher Education, 67, 221-239.

Bringle, R. G., \& Hatcher, J. A. (2000). Institutionalization of service learning in higher education. Journal of Higher Education, 71, 273-290. 
Brooklyn College. (2005). Brooklyn College Strategic Plan 2005-2010. Retrieved on February 15, 2011 from http://www.brooklyn.cuny.edu/bc/president/planning/2010/strategic_plan_2010.p df

Brooklyn College. (2008). Brooklyn College Performance Goals 2008-2009. Retrieved on February 15, 2011 from http://www.brooklyn.cuny.edu/bc/offices/avpbandp/view/planning/performancepr ogressreports/fy2008-2009.pdf

Brooklyn College. (2009). Brooklyn College Performance Goals 2009-2010. Retrieved on February 15, 2011 from http://www.brooklyn.cuny.edu/bc/offices/avpbandp/view/planning/performancein dicators/fy2009-2010.pdf

Brooklyn College. (2010). Draft of Components for Strategic Plan. Retrieved on February 15, 2011 from http://www.brooklyn.cuny.edu/pub/about_bc/documents/Draft_BC_Strat_Plan 11-16-10.pdf

Buchmann, C. \& DiPrete, T. A. (2006). The growing female advantage in college completion: The role of family background and academic achievement. American Sociological Review, 71(4), 515-541.

Carini, R. M., Kuh G. D., \& Klein S. P. (2006). Student engagement and student learning: Testing the linkages. Research in Higher Education, 47(1), 1-32.

Carnegie Foundation for the Advancement of Teaching. (2011). The Carnegie classification of institutions of higher education. Retrieved from http://classifications.carnegiefoundation.org/ on January 31, 2011. 
Chambers, T. (2010). What I hear you saying is...: Analysis of student comments from the NSSE. College Student Journal, 44(1), 3-24. Retrieved on February 14, 2011 from

http://web.ebscohost.com.www.libproxy.wvu.edu/ehost/results?hid=112\&sid=fae 09795-4adc-47c7-b8ef-

9f64blaa8e3a\%40sessionmgr111\&vid $=2 \&$ bquery $=($ WHAT + AND + I + AND + HEA $\mathrm{R}+\mathrm{AND}+\mathrm{YOU}+\mathrm{AND}+\mathrm{SAYING}+\mathrm{AND}+\mathrm{IS} . .+\mathrm{AND}+\mathrm{ANALYSIS}+\mathrm{AND}+\mathrm{OF}+\mathrm{AN}$ $\mathrm{D}+\mathrm{STUDENT}+\mathrm{AND}+\mathrm{COMMENTS}+\mathrm{AND}+\mathrm{FROM}+\mathrm{AND}+\mathrm{THE}+\mathrm{AND}+\mathrm{NSSE}$.) \&bdata=JmRiPWE5aCZ0eXB1PTAmc210ZT1laG9zdC1saXZ1

Chickering, A. W. (1969). Education and identity. San Francisco: Jossey-Bass.

Chickering, A.W. (1974). Commuting versus resident students: Overcoming the educational inequities of living off campus. San Francisco: Jossey-Bass.

Chickering, A.W., \& Gamson, S.F. (1987). Seven principles for good practice in undergraduate education. AAHE Bulletin, 39, 3-7.

City University of New York. (2005). Task force on the City University of New York black male initiative final report to the chancellor. Retrieved on June 18, 2011 from http://www.cuny.edu/academics/initiatives/bmi/task-forcereport/2005_CUNY_BMI_Task_Force_Report_to_the_CUNY_Chancellor__Se ptember_12_2005.pdf

City University of New York. (2010). http://cuny.edu/about.html

City University of New York. (2011a). Total enrollment by race/ethnicity, gender and college: Percentages. Retrieved on July 24, 2011 from http://owl.cuny.edu:7778/ENRL_0033_RACE_GEN_UG_PCT.rpt.pdf

City University of New York. (2011b). CUNY 2008-2012 master plan. Retrieved on February 22, 2011 from

http://www.cuny.edu/about/administration/offices/bf/CUNYMasterplan-200812.pdf

City University of New York. (2011c). Total enrollment by undergraduate and graduate level, gender and college. Retrieved on July 5, 2011 from http://owl.cuny.edu:7778/ENRL_0005_UGGR_GEN.rpt.pdf 
City University of New York. (2011d). Non-discrimination policy. Retrieved on June 9, 2011 from

http://www.cuny.edu/about/administration/offices/ohrm/diversity/StrategicInitiati ves.html

Cohen, A. (1998). The shaping of American higher education. San Francisco, CA: Jossey-Bass.

Coleman, T. (August 16, 2010). NSSE data helps institutions foster minority student success. Diverse Issues in Higher Education. Retrieved from http://diverseeducation.com/article/14039/

Cramer, D. (2003). Advanced quantitative data analysis. London: McGraw-Hill.

Cramer, R. J., \& Prentice-Dunn, S. (2007). Caring for the whole person: guidelines for advancing undergraduate mentorship. College Student Journal, Dec2007 Part A, 41(4), 755-770.

Creswell, J. W. (2009). Research design. Los Angeles, CA: Sage publications.

Crook, D. \& Littman, C. (2010). Patterns of student-student and student-faculty interactions at CUNY: Implications for increasing student engagement. Retrieved on December 17, 2010 from

http://owl.cuny.edu:7778/portal/page/portal/oira/OIRA_HOME/nsse_ses_caao_cs ao.pdf

Degen, G. \& Sheldahl, E. (2007). The many hats of teaching small colleges: The seamless web of student and academic affairs. New Directions for Student Services, 117, 47-56.

DiPrete, T. A. \& Buchmann, C. (2006). Gender-specific trends in the value of education and the emerging gender gap in college completion. Demography, 43(1), 1-24.

Evans, N. J., Forney, D. S., \& Guido-DiBrito, F. (1998). Student development in college: Theory, research, and practice. San Francisco: Jossey-Bass.

Ewell, P. T. (1997). Organizing for learning. AAHE Bulletin, 50(4), 3-6.

Fleming, J. (1984). Blacks in college. San Francisco: Jossey-Bass.

Flowers, L. A. (2004). Examining the effects of student involvement on African American college student development. Journal of College Student Development, 45(6), 633-654. 
Foubert, J. D. \& Grainger, L. U. (2006). Effects of involvement in clubs and organizations on the psychosocial development of first-year and senior college students. NASPA Journal, 43(1), 166-182.

Foner, N. (2000). From Ellis Island to JFK: New York's two great waves of immigration. New Haven: Yale University Press.

Freeman, K. (1998). African Americans and college choice: Cultural considerations and policy implications. In K. Freeman (Ed.), African American culture and heritage in higher educational research and policy (pp. 181-194). Westport, CT: Praeger Publishers.

Gall, M. D., Borg, W. R., \& Gall, J. P. (1996). Educational research: An introduction. White Plains, NY: Longman.

Gallini, S. M. \& Moely, B. E. (2003). Service-learning and engagement, academic challenge, and retention. Michigan Journal of Community Service Learning, 10(1), 5-14.

Gladwell, M. (2008). Outliers: The story of success. New York, NY: Hatchette Book Group.

Gokhale, A. A. (1995). Collaborative learning enhances critical thinking. Journal of Technology Education, 7(1), 22-30.

Harper, S. R. (2008). The effects of sorority and fraternity membership on class participation and African American student engagement in predominantly White classroom environments. College Student Affairs Journal, 27(1), 94-115.

Harper, S. R., Karini, R. M., Bridges, B. K., \& Hayek, J. C. (2004). Gender differences in student engagement among African American undergraduates at historically black colleges and universities. Journal of College Student Development, 45(30), 271-284.

Harper, S.R. \& Quaye, S. J. (2007). Student organizations as venues for black identity expression and development among African American male student leaders. Journal of College Student Development, 48(2), 127-144. 
Hernandez, K., Hogan, S., Hathaway, C., \& Lovell, C. D. (1999). Analysis of the literature on the impact of student involvement on student development and learning: More questions than answers? NASPA Journal, 36(3), 184-197.

Higher Education Research Institute. (2011). Home of Cooperative Institutional Research Program. Retrieved on February 23, 2011 from http://www.heri.ucla.edu/abtcirp.php

Horn, L., Nevill, S., Griffith, J. (2006). Profiles of undergraduates in U.S. postsecondary education institutions, 2003-04: With a special analysis of community college students. Statistical Analysis Report.Washington, D.C.: National Center for Education Statistics.

Huba, M. E. \& Freed, J. (2000). Learner-centered assessment on college campuses: Shifting the focus from teaching to learning. Needham Heights, MA: Allyn \& Bacon.

Institute for Higher Education. (2007). The Beams Beat, Issue 9, September 2007. Retrieved February 14, 2011 from http://www.ihep.org/programs/BEAMS.cfm

Institute for Higher Education. (2008). The Beams Beat, Issue 11, March 2008. Retrieved February 14, 2011 from http://www.ihep.org/programs/BEAMS.cfm

Jacob, B. A. (2002). Where the boys aren't: Non-cognitive skills, returns to school, and the gender gap in higher education. Economics of Education Review, 21, 589598.

Jacoby, B. (1989). The student-as-commuter: Developing a comprehensive institutional response. ASHE-ERIC Higher Education Report No. 7. Washington, DC: The George Washington University.

Jacoby, B. (2000). Why involve commuter students in learning? New Directions for Teaching and Learning, 109, 3-12.

Kezar, A., \& Kinzie, J. (2006). Examining the ways institutions create student engagement: the role of mission. Journal of College Student Development, 47(2). 149-172. 
Kimbrough, W. M. (1995). Self-assessment, participation, and value of leadership skills, activities, and experiences for Black students relative to their membership in historically Black fraternities and sororities. Journal of Negro Education, 64, 63-74.

Kimbrough, W. M., \& Hutcheson, P. A. (1998). The impact of membership in black greek-letter organizations on black students' involvement in collegiate activities and their development of leadership skills. Journal of Negro Education, 67, 96105.

Kinzie, J., Gonyea, R., Shoup, R., \& Kuh, G. D. (2008). Promoting persistence and success of underrepresented students: Lessons for teaching and learning. New Directions for Teaching and Learning, 115. 21-38.

Kinzie, J., \& Kuh, G. D. (2004). Going DEEP: Learning from campuses that share responsibility for student success. About Campus, 9(5), 2-8.

Kuh, G. D. (1993). In their own words: what students learn outside the classroom. In F. K. Stage (Ed.), College students: The evolving nature of research (pp. 101-122). Needham Heights, MA: Simon \& Schuster Custom Publishing.

Kuh, G. D. (2001a). The national survey of student engagement: Conceptual framework and overview of psychometric properties. Bloomington, IN: Indiana University Center for Postsecondary Research.

Kuh, G. D. (2001b). Assessing what really matters to student learning: Inside the National Survey of Student Engagement. Change, 33(3), 10-17, 66.

Kuh, G. D. (2003). What we're learning about student engagement from NSSE: Benchmarks for effective educational practices. Change, 35(2), 24-32.

Kuh, G. D. (2009). What student affairs professionals need to know about student engagement. Journal of College Student Development, 50(6), 683-706.

Kuh, G. D., Cruce, T. M., Shoup, R., \& Kinzie, J. (2008). Unmasking the effects of student engagement on first-year college grades and persistence. Journal of Higher Education, 79(5). 540-563.

Kuh, G. D., Gonyea, R. M., \& Palmer, M. (2001). The disengaged commuter: Fact or fiction? Commuter Perspectives, 27(1), 2-5.

Kuh, G. D., and Hu, S. (2001). The effects of student-faculty interaction in the 1990s. Review of Higher Education, 24(3), 309-332. 
Kuh, G. D., Kinzie, J., Buckley, J. A., Bridges, B. K., \& Hayek, J. C. (2006). What matters to student success: A review of the literature. Commissioned report for the National Symposium on Postsecondary Student Success: Spearheading a Dialog on Student Success. Washington, DC: National Postsecondary Education Cooperative.

Kuh, G. D., Kinzie, J., Cruce, T., Shoup, R., \& Gonyea, R. M. (2007). Connecting the dots: Multi-faceted analyses of the relationships between student engagement results from the NSSE, and the institutional practices and conditions that foster student success. Revised final report prepared for Lumina Foundation for Education Grant \#2518. Retrieved February 23, 2011 from http://nsse.iub.edu/pdf/Connecting_the_Dots_Report.pdf

Kuh, G. D., Kinzie, J., Schuh, J. H., and Whitt, E. J., et al. (2010). Student success in college: Creating conditions that matter. San Francisco, CA: Jossey-Bass.

Kuh, G. D., Whitt, E. J., \& Strange, C. C. (1989). The contributions of institutional agents to high quality out-of-class experiences for college students. Paper presented at the annual meeting of the American Educational Research Association. San Francisco, CA, 27-31 March.

LaBoone, K. L. (2006). Minority students' transition experiences at a predominantly white institution. Dissertation Abstract International, 67(2), 483A. (UMI No. AAT 3207971)

Retrieved July 20, 2010, from Dissertations and Theses database.

Laird, T. F., Bridges, B. K., Morelon-Quainoo, C. L., \& Williams, J. M. (2007). African American and Hispanic student engagement at minority serving and predominantly white institutions. Journal of College Student Development, 48(1). 39-56.

Leinbach, D. T. \& Bailey, T. R. (2006). Access and achievement of Hispanics and Hispanic immigrants in the colleges of the City University of New York. Community College Research Center. Retrieved June 30, 2011 from http://ccrrc.tc.columbia.edu/Publication.asp?UID=381

Lucas, C. J., (2006). American higher education. New York, NY: Palgrave Macmillan. 
Lundberg, C.A. \& Schreiner, L.A. (2004). Quality and frequency of faculty-student interaction as predictors of learning: An analysis by student race/ethnicity. Journal of College Student Development, 45(5), 549-565.

Mickens, K. M. (2007). Non-greek African American undergraduate student attitudes about black greek lettered organizations, black greek lettered members, the membership intake process, pledging and hazing within black greek lettered organizations. Dissertation Abstract International, 68(1). (UMI No. AAT 3246680) Retrieved July 20, 2010, from ProQuest Digital Dissertations database.

Morison, S. E. (1936). Harvard College in the seventeenth century. Cambridge, MA: Harvard University Press.

Museus, S. D. \& Quaye, S. J. (2009). Toward an intercultural perspective of racial and ethnic minority college student persistence. The Review of Higher Education, 33(1), 67-94.

National Center for Education Statistics. (2005). Gender differences in participation and completion of undergraduate education and how they have changed over time. Washington, DC: U.S. Department of Education Institute of Education Sciences. Retrieved June 1, 2011 from http://nces.ed.gov/pubs2005/2005169.pdf

National Center for Education Statistics. (2010). Status and trends in the education of racial and ethnic groups. Washington, DC: U.S. Department of Education Institute of Education Sciences. Retrieved June 1, 2011 from http://nces.ed.gov/pubs2010/2010015.pdf

National Survey of Student Engagement (2004). 2004 Overview. Blomington, IN: Indiana University Center for Postsecondary Research. Retrieved June 1, 2011 from http://nsse.iub.edu/pdf/2004_inst_report/overview.pdf

National Survey of Student Engagement (2005). The NSSE 2005 annual report: Exploring different dimensions of student engagement. Bloomington, IN: Indiana University Center for Postsecondary Research. Retrieved December 5, 2010 from http://nsse.iub.edu/pdf/NSSE2005_annual_report.pdf 
National Survey of Student Engagement (2006). The NSSE 2006 annual report:

National benchmarks of effective educational practice. Bloomington, IN: Indiana University Center for Postsecondary Research. Retrieved December 5, 2010 from http://nsse.iub.edu/NSSE_2006_Annual_Report/docs/NSSE_2006_Annual_Repor t.pdf

National Survey of Student Engagement. (2008). Promoting engagement for all students: The imperative to look within-Annual results 2008. Bloomington, IN: Indiana University Center for Postsecondary Research. Retrieved December 5, 2010 from

http://nsse.iub.edu/NSSE_2008_Results/docs/withhold/NSSE2008_Results_revis ed_11-14-2008.pdf

National Survey of Student Engagement. (2009). Assessment for improvement:

Tracking student engagement over time-Annual results 2009. Bloomington, IN: Indiana University Center for Postsecondary Research. Retrieved December 5, 2010 from http://nsse.iub.edu/NSSE_2009_Results/pdf/NSSE_AR_2009.pdf

National Survey of Student Engagement. (2010). NSSE 2010 Overview. Bloomington, IN: Indiana University Center for Postsecondary Research. Retrieved February 14, 2011 from http://nsse.iub.edu/2010_Institutional_Report/pdf/NSSE\%20Overview_2010.pdf

National Survey of Student Engagement. (2011). Benchmarks of effective educational practice. Retrieved February 14, 2011 from http://nsse.iub.edu/pdf/nsse_benchmarks.pdf

Nora, A. \& Cabrera A. F. (1996). The role of perceptions of prejudice and discrimination on the adjustment of minority students to college. Journal of Higher Education, 67(2), 119-148.

NSSE Institute for Effective Educational Practice. (2011). Project DEEP Overview. Retrieved June 1, 2011 from http://nsse.iub.edu/institute/?view=deep/overview

Pace, C. R. (1979). Measuring outcomes of college. San Francisco: Jossey-Bass.

Pace, C. R. (1984). Measuring the quality of student experiences: An account of the development and use of the college student experiences questionnaire. Los Angeles: Higher Education Research Institute, University of California, Los Angeles. 
Pascarella, E. T., Edison, M., Whitt, E. J, Nora, A., Hagedorn, L. S., \& Terenzini, P. T. (1996). Cognitive effects of Greek membership during the first-year of college. NASPA Journal, 33, 242-259.

Pascarella, E. T., \& Terenzini, P. T. (1991). How college affects students: Findings and insights from twenty years of research. San Francisco: Jossey-Bass.

Pascarella, E.T., \& Terenzini, P.T. (2005). How college affects students: Volume 2: A third decade of research. San Francisco: Jossey-Bass.

Patton, M. Q. (2002). Qualitative research and evaluation methods. Thousand Oaks, California: Sage Publications, Inc.

Pike, G. R. (2000). The influence of fraternity or sorority membership on students' college experiences and cognitive development. Research in Higher Education, 41(1), 117-139.

Pike, G. R., \& Kuh, G. D. (2005). A typology of student engagement for American colleges and universities. Research in Higher Education, 46, 185-210.

Prince, M. (2004). Does active learning work? A review of the research. Journal of Engineering Education, 93(3), 223-231.

Quaye, S. J., \& Harper, S. R. (2007). Shifting the onus from racial/ethnic minority students to faculty: Accountability for culturally inclusive pedagogy and curricula. Liberal Education, 93(3), 32-39.

Radford, A. W., Berkner, L., Wheeless, S. C., \& Shepherd, B. (2010). Persistence and attainment of 2003-04 beginning postsecondary students: After 6 years (NCES 2011-151). U.S. Department of Education. Washington, DC: National Center for Education Statistics. Retrieved December 9, 2010 from http://nces.ed.gov/pubsearch

Senge, P. M. (2000). Building learning organizations. In M. Christopher Brown (Ed.), Organization and governance in higher education (pp. 287-304). Boston: Pearson Custom Publishing.

Spellings Commission. (2006). A test of leadership: Charting the future of U.S. higher education. Retrieved on April 20, 2011 from http://www2.ed.gov/about/bdscomm/list/hiedfuture/reports/pre-pub-report.pdf

Sutton, E. M., \& Kimbrough, W. M. (2001). Trends in black student involvement. NASPA Journal, 39(1), 30-40. 
Swail, W. S., Redd, K. E., \& Perna, L. W. (2003). Retaining minority students in higher education: A framework for success. ASHE-ERIC Higher Education Report 30(2). San Francisco: Jossey-Bass.

Terenzini, P. T., Rendon, L. I., Upcraft, M. L., Millar, S. B., Allison, K. W., Gregg, P. L., \& Jalomo, R. (1993). The transition to college: Diverse students, diverse stories. In F.K. Stage (Ed.), College students: The evolving nature of research (pp. 5465). Needham Heights, MA: Simon \& Schuster Custom Publishing.

Thelin, J. R. (2006). A history of American higher education. Baltimore, MD: The Johns Hopkins University Press.

Thomas, G. E. (1981). Black students in higher education. Westport, CT: Greenwood Press.

Tierney, W.G. (1997). Power, identity, and the dilemma of college student departure. (Draft. University of Southern California). Retrieved from http://www.usc.edu/dept/chepa/pdf/power.pdf.

Tinto, V. (1987). Leaving college: Rethinking the causes and cures of student attrition. Chicago: University of Chicago Press.

Tinto, V. (1993). Leaving college: Rethinking the causes and cures of student attrition, $\left(2^{\text {nd }}\right.$ ed.). Chicago: University of Chicago Press.

Townsend, L. (1994). How universities successfully retain and graduate black students. The Journal of Blacks in Higher Education, 4, 85-89.

Umbach, P. D. \& Wawrzynski, M. R. (2005). Faculty do matter: The role of college faculty in student learning and engagement. Research in Higher Education, 46(2), 153-184.

United States Department of Labor. (2011). Title IX, Education Amendments of 1972. Retrieved July 24, 2011 from http://www.dol.gov/oasam/regs/statutes/titleix.htm

Warren, R. G. (1997). Engaging students in active learning. About Campus: Enriching the Student Learning Experience, 2, 16-20.

Williamson, J. A. (1999). In defense of themselves: The Black student struggle for success and recognition at pre-dominantly White colleges and universities. Journal of Negro Education, 68(1) 92-105.

Zeta Phi Beta Sorority, Incorporated. (2011). Signature Programs. http://zphib1920.org/zhope.html 


\section{National Survey of Student Engagement 2009 The College Student Report}

1 In your experience at your institution during the current school year, about how often have you done each of the following? Mark your answers in the boxes. Examples: $邓$ or
a. Asked questions in class or contributed to class discussions

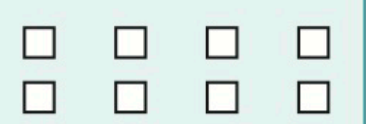
r. Worked harder than you thought you could to meet an instructor's standards or expectations
b. Made a class presentation
c. Prepared two or more drafts of a paper or assignment before turning it in
d. Worked on a paper or project that required integrating ideas or information from various sources
e. Included diverse perspectives (different races, religions, genders, political beliefs, etc.) in class discussions or writing assignments
f. Come to class without completing readings or assignments
g. Worked with other students on projects during class
h. Worked with classmates outside of class to prepare class assignments
i. Put together ideas or concepts from different courses when completing assignments or during class discussions
j. Tutored or taught other students (paid or voluntary)
k. Participated in a community-based project (e.g., service learning) as part of a regular course
I. Used an electronic medium (listserv, chat group, Internet, instant messaging, etc.) to discuss or complete an assignment
m. Used e-mail to communicate with an instructor
$\mathrm{n}$. Discussed grades or assignments with an instructor
o. Talked about career plans with a faculty member or advisor
p. Discussed ideas from your readings or classes with faculty members outside of class
q. Received prompt written or oral feedback from faculty on your academic performance

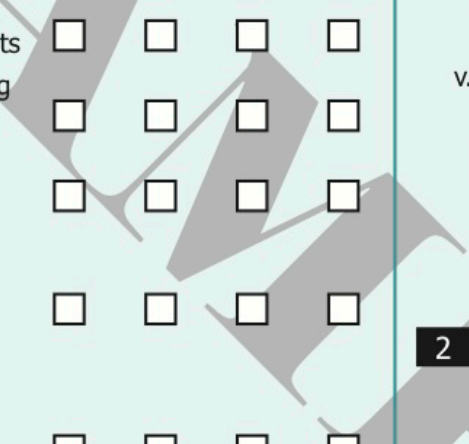
s. Worked with faculty members on activities other than coursework (committees, orientation, student life activities, etc.)
t. Discussed ideas from your readings or classes with others outside of class (students, family members, co-workers, etc.)
u. Had serious conversations with students of a different race or ethnicity than your own
v. Had serious conversations with students who are very different from you in terms of their religious beliefs, political opinions, or personal values

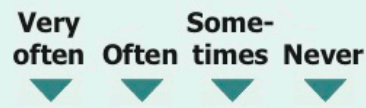 often Often times Never
2 During the current school year, how much has your coursework emphasized the following mental activities?
a. Memorizing facts, ideas, or Very Quite Very mental activities? methods from your courses and readings so you can repeat them in pretty much the same form
b. Analyzing the basic elements of an idea, experience, or theory, such as examining a particular case or situation in depth and considering its components
c. Synthesizing and organizing much a bit Some little ideas, information, or experiences into new, more complex interpretations and relationships
d. Making judgments about the value of information, arguments, or methods, such as examining how others gathered and interpreted data and assessing the soundness of their conclusions
e. Applying theories or concepts to practical problems or in new situations 
3 During the current school year, about how much reading and writing have you done?

a. Number of assigned textbooks, books, or book-length packs of course readings

$\begin{array}{llccc}\square & \square & \square & \square & \square \\ \text { None } & 1-4 & 5-10 & 11-20\end{array}$

b. Number of books read on your own (not assigned) for personal enjoyment or academic enrichment

$\begin{array}{lllll}\square & \square & \square & \square & \square \\ \text { None } & 1-4 & 5-10 & 11-20\end{array}$

c. Number of written papers or reports of $\mathbf{2 0}$ pages or more

$\begin{array}{llccc}\square & \square & \square & \square \\ \text { None } & 1-4 & \square-10 & 11-20\end{array}$

d. Number of written papers or reports between 5 and 19 pages $\begin{array}{llll}\square & \square & \square & \square\end{array}$

e. Number of written papers or reports of fewer than $\mathbf{5}$ pages $\square \quad \square \quad \square \quad \square \quad \square \quad \square \quad \square \quad$ None than 20

4 In a typical week, how many homework problem sets do you complete?

a. Number of problem sets that take you more than an hour to complete

b. Number of problem sets that take you less than an hour to complete

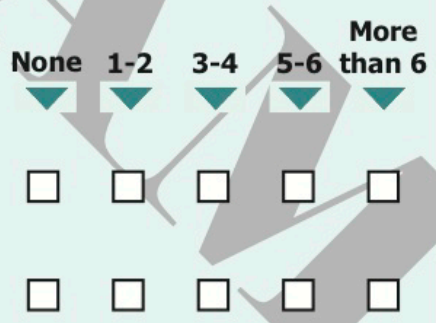

5 Mark the box that best represents the extent to which your examinations during the current school year have challenged you to do your best work. Very little

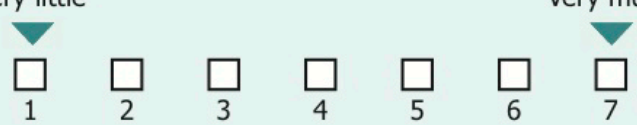

6 During the current school year, about how often have you done each of the following?
a. Attended an art exhibit, play, dance, music, theater, or other performance
b. Exercised or participated in physical fitness activities
c. Participated in activities to enhance your spirituality (worship, meditation, prayer, etc.)
d. Examined the strengths and weaknesses of your own views on a topic or issue
e. Tried to better understand someone else's views by imagining how an issue looks from his or her perspectiv
f. Learned something that changed the way you understand an issue or concept

7 Which of the following have you done or do you plan to do before you graduate from your institution?

a. Practicum, internship, field experience, co-op experience, or clinical assignment

b. Community service or volunteer work

c. Participate in a learning community or some other formal program where groups of students take two or more classes together

d. Work on a research project with a faculty member outside of course or program requirements

e. Foreign language coursework

f. Study abroad

g. Independent study or self-designed major

h. Culminating senior experience (capstone course, senior project or thesis, comprehensive exam, etc.)

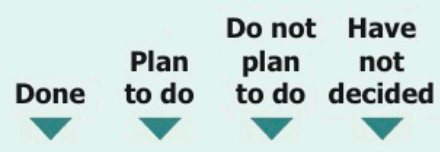

8 Mark the box that best represents the quality of your relationships with people at your institution.

a. Relationships with other students

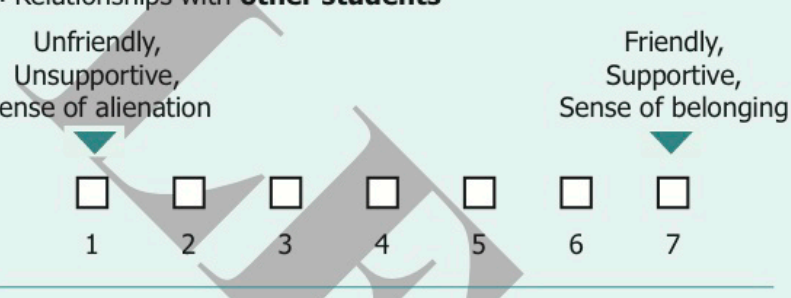

b. Relationships with faculty members

Unavailable,

Unhelpful,

Unsympathetic

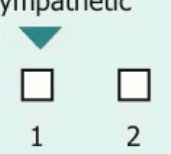

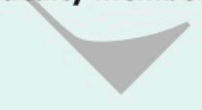

\section{Available, \\ Helpful,} Sympathetic

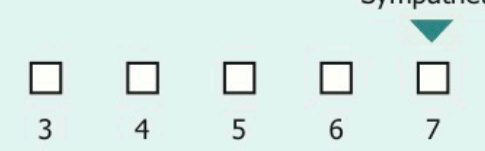

c. Relationships with administrative personnel and offices

Unhelpful,

Inconsiderate,

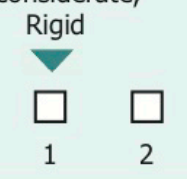

Helpful,

Considerate, Flexible 
About how many hours do you spend in a typical 7-day week doing each of the following?

a. Preparing for class (studying, reading, writing, doing homework or lab work, analyzing data, rehearsing, and other academic activities)

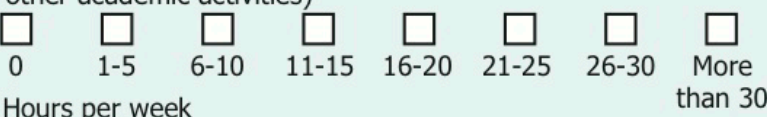

b. Working for pay on campus

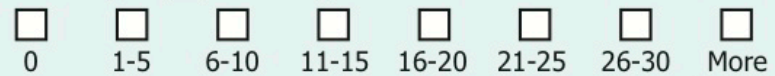

Hours per week

than 30

c. Working for pay off campus

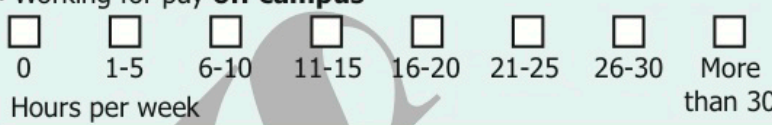

d. Participating in co-curricular activities (organizations, campus publications, student government, fraternity or sorority, intercollegiate or intramural sports, etc.)

$\square \quad \square \quad \square \quad \square_{0}^{\square-10} \square_{11-15}^{\square} \underset{16-20}{\square} \quad \square \quad \square$

Hours per week

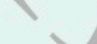

than 30

e. Relaxing and socializing (watching TV, partying, etc.)

$\square \quad \square \quad \square \quad \square_{1-5} \square \square_{11-15}^{\square} \square_{16-20}^{\square} \underset{21-25}{\square} \square_{26-30}^{\square}$

Hours per week

f. Providing care for dependents living with you (parents, children, spouse, etc.)

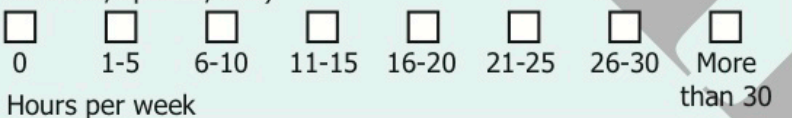

Hours per week

g. Commuting to class (driving, walking, etc.)

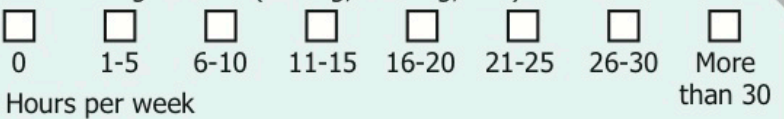

To what extent does your institution emphasize each of the following?

a. Spending significant amounts of time studying and on academic work

b. Providing the support you need to help you succeed academically

c. Encouraging contact among students from different economic, social, and racial or ethnic backgrounds

d. Helping you cope with your nonacademic responsibilities (work, family, etc.)

e. Providing the support you need to thrive socially

f. Attending campus events and activities (special speakers, cultural performances, athletic events, etc.)

g. Using computers in academic work
11 To what extent has your experience at this institution contributed to your knowledge, skills, and personal development in the following areas?

a. Acquiring a broad general education

b. Acquiring job or work-related knowledge and skills

c. Writing clearly and effectively

d. Speaking clearly and effectively

e. Thinking critically and analytically

f. Analyzing quantitative problems

g. Using computing and information technology

h. Working effectively with others

i. Voting in local, state, or national elections

j. Learning effectively on your own

k. Understanding yourself

I. Understanding people of other racial and ethnic backgrounds

m. Solving complex real-world problems

n. Developing a personal code of values and ethics

o. Contributing to the welfare of your community

p. Developing a deepened sense of spirituality

$\begin{array}{ll}\text { Very Quite } & \text { Very } \\ \text { much a bit Some little }\end{array}$

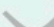

2 Overall, how would you evaluate the quality of academic advising you have received at your institution?
$\square$ Excellent
$\square$ Good
$\square$ Fair
$\square$ Poor

13 How would you evaluate your entire educational experience at this institution?

$\square$ Excellent

$\square$ Good

$\square$ Fair

$\square$ Poor

14 If you could start over again, would you go to the same institution you are now attending?
$\square$ Definitely yes
$\square$ Probably yes
$\square$ Probably no
$\square$ Definitely no 
15 Write in your year of birth:

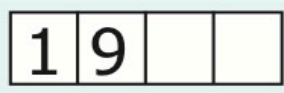

16 Your sex:

Male

Female

17 Are you an international student or foreign national?

$\square$ Yes No

18 What is your racial or ethnic identification? (Mark only one.)

$\square$ American Indian or other Native American

$\square$ Asian, Asian American, or Pacific Islander

$\square$ Black or African American

$\square$ White (non-Hispanic)

$\square$ Mexican or Mexican American

$\square$ Puerto Rican

$\square$ Other Hispanic or Latino

$\square$ Multiracial

$\square$ Other

I prefer not to respond

19 What is your current classification in college?

$\square$ Freshman/first-year

$\square$ Senior

Sophomore

$\square$ Unclassified

Junior

20 Did you begin college at your current institution or elsewhere?

$\square$ Started here $\square$ Started elsewhere

21 Since graduating from high school, which of the following types of schools have you attended other than the one you are attending now? (Mark all that apply.)

$\square$ Vocational or technical school

$\square$ Community or junior college

$\square$ 4-year college other than this one

$\square$ None

$\square$ Other

22 Thinking about this current academic term, how would you characterize your enrollment?
$\square$ Full-time
Less than full-time

Are you a member of a social fraternity or sorority?

$\square$ Yes

$\square$ No
24 Are you a student-athlete on a team sponsored by your institution's athletics department?
$\square$ Yes
$\square$ No (Go to question 25.)

$\downarrow$

On what team(s) are you an athlete (e.g., football, swimming)? Please answer below:

What have most of your grades been up to now at this institution?
$\square$ A
$\square$ B +

$\square c+$
$\square c$
$\square$ c- or lower

26 Which of the following best describes where you are living now while attending college?

$\square$ Dormitory or other campus housing (not fraternity/ sorority house)

$\square$ Residence (house, apartment, etc.) within walking distance of the institution

$\square$ Residence (house, apartment, etc.) within driving distance of the institution

$\square$ Fraternity or sorority house

None of the above

27 What is the highest level of education that your parent(s) completed? (Mark one box per column.) Father Mother

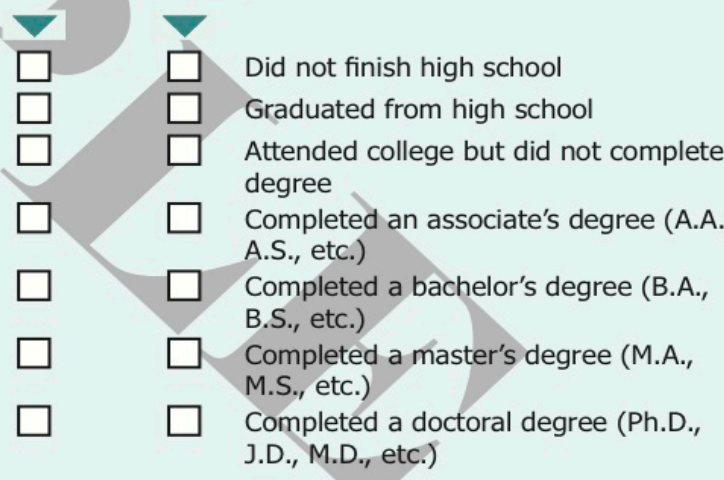

28 Please print your major(s) or your expected major(s).

a. Primary major (Print only one.):

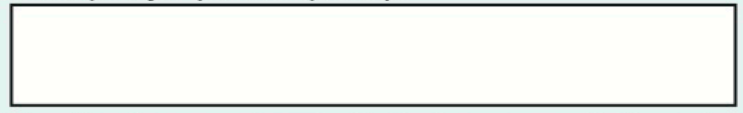

b. If applicable, second major (not minor, concentration, etc.):

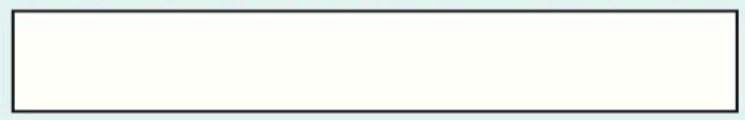

\section{THANKS FOR SHARING YOUR RESPONSES!}

After completing the survey, please put it in the enclosed postage-paid envelope and deposit it in any U.S. Postal Service mailbox. Questions or comments? Contact the National Survey of Student Engagement, Indiana University, 1900 East Tenth Street, Suite 419, Bloomington IN 47406-7512 or nsse@indiana.edu or www.nsse.iub.edu. Copyright @ 2008 Indiana University. 


\section{Appendix: B}

\section{We West VirginiaUniversity \\ College of Human Resources and Education}

April 26, 2011

CUNY Office of Institutional Research and Assessment 555 West $57^{\text {th }}$ Street, Suite 1240

New York, NY 10019

Dear Dr. Littman,

Thank you for your willingness to assist me in securing data from your institution as part of my dissertation research on what influences successful Black commuter students' engagement in college. For the purpose of my study, I am defining success as Black senior students who have maintained at least a $\mathrm{C}$ overall grade point average (GPA) at CUNY.

The purpose of this study is to assess successful Black college students' engagement in educational practices associated with high levels of learning and development on CUNY campuses in an attempt to improve student engagement and, ultimately, learning. Secondly, this study will offer recommendations to administrators and faculty in higher education that could help enhance the success of Black commuter students.

I am requesting access to CUNY's 2009 National Survey of Student Engagement (NSSE) data results. The data collected in this study will strictly be used for completion of my dissertation requirements. I will share my findings with you in an executive summary upon your request. Attached is CUNY's research determination form, which gives me permission to conduct this study using CUNY's 2009 NSSE data. If you have any questions please do not hesitate to contact me at 347.739 .1406 or via email at trinayearwood@aol.com.

Thank you,
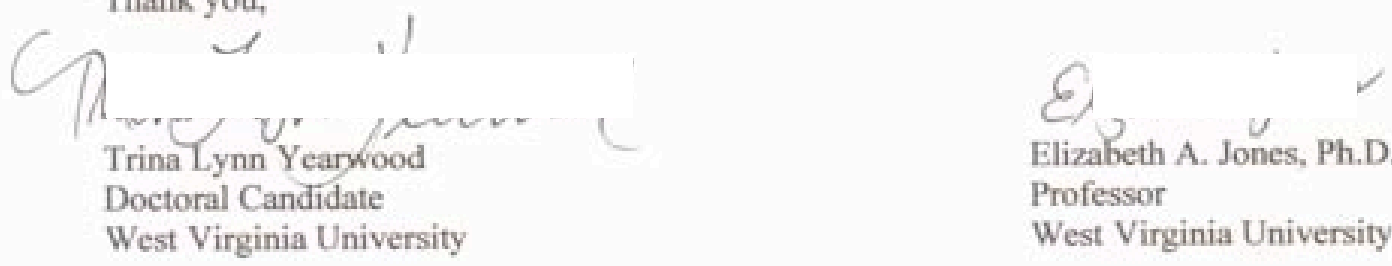

Educational Leadership Studies

608 Allon Hall 